\title{
Response of phytoplankton to organic enrichment and shrimp activity in tropical aquaculture ponds: a mesocosm study
}

\author{
Lemonnier Hugues ${ }^{1,{ }^{*}}$, Hochard Sebastien ${ }^{1}$, Nakagawa $\mathrm{K}^{1,2}$, Courties $\mathrm{C}^{3}$, Rodier $\mathrm{M}^{4}$
}

1 IFREMER LEAD, BP 2059, 98846, Nouméa Cedex, New Caledonia

2 LTMA, applied technology and technology transfer laboratory, Koné, New Caledonia

${ }^{3}$ Sorbonne Universités, UPMC Univ. Paris 6, UMS 2348 Observatoire Océanologique, F- 66650, Banyuls/mer, France

${ }^{4}$ IRD, Ecosystèmes Insulaires Océaniens (EIO) UMR 241 (Université de la Polynésie française - Institut de Recherche pour le Développement - Institut Malardé-Ifremer), Centre IRD de Tahiti, BP529, 98713 Papeete, French Polynesia

* Corresponding author : Hugues Lemonnier, email address : hugues.lemonnier@ifremer.fr

\begin{abstract}
:
We conducted a mesocosm study to investigate the combined effect of organic enrichment and sediment resuspension by shrimp on phytoplankton communities in shrimp aquaculture ponds. Hence, the factorial design included two factors, i.e., (i) shrimp density with a concomitant increase of feed input resulting in organic enrichment and (ii) with/without access of shrimp to the sediments. Increasing feed input in the system raised the eutrophication state of the environment characterized by an increase in phytoplankton biomass. Bioturbation enhanced (i) mineralization of organic matter via the microbial loop, resulting in faster nutrient recycling, (ii) an increase of primary production, and (iii) buffering capacity against eutrophication consequences. The phytoplankton community showed both large temporal variations of its taxonomic composition and resilience to treatments. A shift in species dominance from Diatoms + Dinoflagellates to green algae was observed in all treatments and coincided with meteorological and $\mathrm{N}$ pool changes. Results suggested that algal production was primarily limited by phosphorus and light at low (i.e. low feeding) and high (i.e. high feeding) eutrophication states, respectively. Growth rate appeared as an important factor of dominance in this highly dynamic ecosystem. Consequences for water column management are discussed.
\end{abstract}

Keywords: Aquaculture, Litopenaeus stylirostris, Phytoplankton communities, eutrophication, bioturbation 


\section{Introduction}

Shallow marine environments are primarily defined to their high ratio of sediment surface area to water volume (McGlathery et al., 2007). These features add complexity on how the system responds to eutrophication particularly due to a strong benthic-pelagic coupling. In shallow eutrophic areas, organic matter loading can enhance sediment respiration and the release of nutrients into the overlying water column that sustain part of the primary producers growth and production (Cloern, 2001; Porter et al., 2010). Eutrophication may also promote the proliferation of certain species, some of which may often cause harm through the production of toxins (Heisler et al., 2008; O'Neil et al., 2012; Paerl and Otten, 2013), a phenomenon known as harmful algal blooms (HAB). Even if the different processes and effects of eutrophication are well known and documented (e.g. Cloern, 2001), the effects on phytoplankton community are not easily predictable (Schmoker et al., 2016), especially in shallow environment. In these areas, wind and storm events, tides, waves, wave-current and bioturbation are involved in the dispersal of sediment particles leading to an increase of the turbidity in the water column. Reduction of light availability may become a limiting factor for primary production, with possible consequences on phytoplanktonic communities and productivity (Rochelle-Newall et al., 2011). There is also evidence that all these physical processes enhance nutrient flux from sediment into the water column (e.g. Haven, 1991) that may also affect phytoplankton biomass and composition (Havens, 1993; Porter et al., 2010). Due to the complexity of the processes involved and to the uncontrollable variability end feedbacks, it is difficult to discriminate the factors influencing water eutrophication within natural shallow ecosystems from in situ measurements (Porter et al., 2010).

Outdoor shrimp aquaculture ponds are artificial marine systems that are shallow $(<2 \mathrm{~m})$ and highly eutrophic associated with elevated nutrient inputs. These systems show low diversity, and simplified trophic chains, where phytoplankton plays a pivotal role in the flow of energy 
and nutrients, due to their high abundance, efficient nutrient uptake and high productivity (Burford, 1997). Phytoplankton cell proliferation linked to increasing inputs of nutrients through feeding has been widely analysed (e.g. Casé et al., 2008). Temporal changes of dominant species due to dynamic variations of growth factors such as light, temperature, substrate supply (inorganic and organic nutrients), predation and virus infection have also been reported (e.g. Burford, 1997; Casé et al., 2008). According to the ecological theory of $\mathrm{r} / \mathrm{K}$ selection, an unstable environment in pond containing high nutrient levels is particularly favorable to select for fast-growing organisms as opportunistic pathogens (De Schryver and Vadstein, 2014). This lack of stability linked to an imbalance in the $\mathrm{N}: \mathrm{P}$ ratio may promote the development of toxic algal species stressful for shrimp, playing directly or indirectly a role in disease outbreaks in shrimp aquaculture ponds in New Caledonia (Lemonnier et al., 2006; Lemonnier et al., 2010; Lucas et al; 2010; Lemonnier et al., 2016).

However, while the role of phytoplankton in maintaining water quality in tropical shrimp ponds has been studied in the field by several authors (e.g. Burford, 1997), few studies have been conducted to distinguish the role of the different factors involved in the control of the phytoplankton community and dynamic. "Stocking density", defined as the number of animals per unit area, is one of the most important factors. Raising shrimp stocking density in ponds requires increased organic matter input for shrimp feeding. As a result, more waste - mainly faeces and unconsumed feed pellets - is produced, leading to an increase of the eutrophication level of the pond ecosystem (Martin et al., 1998; Bouwman et al., 2013). The nutrients, produced through organic matter degradation or excreted by shrimps, are rapidly assimilated by phytoplankton. This results in low concentrations of inorganic nutrients in the water column (Burford and Williams, 2001; Burford et al., 2003). Moreover, shrimp act as bioengineers in ponds and have large physical and biogeochemical impacts on sediment 
through their bioturbation. Therefore, any modifications of shrimp stocking density will affect processes linked to the bioturbation (Ritvo et al., 1997; Ritvo et al., 2004; Joyni et al., 2011).

Due to the complexity of physical and biological processes in the field, it is difficult to distinguish the effect of each forcing variable on phytoplankton community, function and dynamic. To overcome this difficulty, we set up highly controlled experiments in mesocosms. This paper reports the results of an experiment in which i) different densities of shrimp with their corresponding amounts of feed inputs and ii) access/no access to sediment were studied according a factorial approach to disentangle the effects organic matter input by feeding from the effects of shrimp activity on sediment by bioturbation. Because few studies address both changes to perturbation in composition and in functionality, making the generalization of patterns difficult (Nogales et al., 2011), phytoplankton communities were followed through flow cytometry (FCM) and spectrofluorometry, in close relationship with the biogeochemical functioning of the water column. The aim of this work is to improve our knowledge of phytoplankton ecology in outdoor pond aquaculture and, more generally, in eutrophicated ecosystems. By improving our knowledge in this field, this should facilitate the implementation of technical measures, to increase efficiency in recycling waste produced during rearing and limit the risk of growth of harmful species (Vibrio spp., harmful algae...).

\section{Materials and methods}

\subsection{Experimental set-up}

The mesocosm experiment was conducted over a 44-day period from 7 November to 21 December 2011 at the Saint-Vincent aquaculture research centre, located on the west coast of

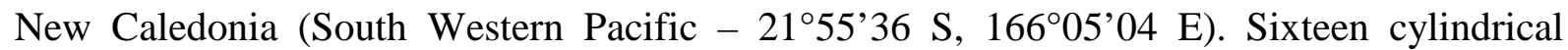
polyethylene tanks, each with an effective volume of about 16001 and a surface area of 1.72 $\mathrm{m}^{2}$, were used in an outdoor area. The bottom of each mesocosm was filled with a $20 \mathrm{~cm}$ thick 
layer of dry and natural sediment. The sediment was collected on salted and unvegetated intertidal zone between mangroves and agricultural land, which is where shrimp farms are generally located in New Caledonia. Sediment grain size was predominantly within the silty clay fraction and sediment organic content was below $2 \%$. Each tank was filled with sea water (0.8 $\mathrm{m}$ depth) pumped from the nearby bay (called the "inaccessible" bay) and previously filtered through a $4 \mathrm{~mm}$ filter.

We crossed different densities of shrimp (D) with access or no access to sediment $\left(\mathrm{S}^{+} / \mathrm{S}^{-}\right)$in a $2 \times 2$ factorial experiment run in triplicate. Enclosures preventing access to the sediment (S) were constructed with netting (mesh: $1.5 \mathrm{~cm}$ ) and were positioned in tanks about $20 \mathrm{~cm}$ from the sediment. These enclosures prevented shrimp from accessing the sediment and thus from feeding on the benthic community and acting as bioturbators of the sediment. However, they did not alter sedimentation and water-sediment nutrient exchanges to occur. The tanks were stocked with Litopenaeus stylirostris juvenile shrimp, the species commonly reared in New Caledonia, at 4 shrimp $\mathrm{m}^{-2}$ (D4 for low density) or at 12 shrimp $\mathrm{m}^{-2}$ (D12 for high density). The weight of each individual was $9.0 \pm 1.5 \mathrm{~g}$ and the stocking density at the beginning of the experiment in D4 and D12 tanks was about 37 and $110 \mathrm{~g} \mathrm{~m}^{-2}$, respectively. D12 was designed to mimic the density generally found in shrimp aquaculture ponds in New Caledonia. Throughout the experiment, shrimp were fed twice a day using feeding trays with commercial pellets with $35-40 \%$ protein content. The mean daily feed input was $1.3 \mathrm{~g} \mathrm{~m}^{-2}$ and $3.8 \mathrm{~g} \mathrm{~m}^{-2}$, representing a total feed input over the 44-day experiment of 50 and $150 \mathrm{~g} \mathrm{~m}^{-2}$ for D4 and D12, respectively.

Four combinations were thus tested in triplicate, allocated randomly to the 12 tanks: (1) high shrimp density + access to the sediment $\left(\mathrm{D} 12 \mathrm{~S}^{+}\right)$, (2) high density - access (D12S ) (3) low density + access $\left(\mathrm{D}^{4} \mathrm{~S}^{+}\right)$, (4) low density - access $\left(\mathrm{D}^{-} \mathrm{S}^{-}\right)$. Four other tanks without shrimp were used as controls, two without enclosure $\left(\mathrm{D}_{0} \mathrm{~S}^{+}\right)$and two with enclosure (D0S $)$. The 
water was renewed daily in each tank by pumping water from the nearby bay (named the "inaccessible" bay), at $20 \% \pm 3 \%$ of the total volume as generally applied in shrimp farms. The inner walls of the tanks were cleaned twice weekly to reduce the effect of periphyton biomass and production on the experimental system (Chen and Kemp, 2004). At the end of the experiment, all shrimp were harvested so as to calculate the survival rate, mean final weight, biomass produced in each tank.

\subsection{Sampling and in situ measurements}

Photosynthetically active radiation PAR $(\sim 400-700 \mathrm{~nm})$ was measured $1 \mathrm{~m}$ above the mesocosms with a $1 \mathrm{~s}$ step and averaged each day using a LI-COR quantum sensor and LICOR Li1400 data logger. Daily rainfall data were measured at proximity of the experimental facilities $(<100 \mathrm{~m})$ and obtained from the local weather forecast service (Météo-France, Nouméa). Water temperature was automatically and continuously monitored with a $1 \mathrm{~h}$ step randomly in five tanks using thermo buttons (Proges plus). In 8 tanks (two per treatment $\mathrm{D} 12 \mathrm{~S}^{+}, \mathrm{D} 12 \mathrm{~S}^{-}, \mathrm{D} 4 \mathrm{~S}^{+}$and $\mathrm{D} 4 \mathrm{~S}^{-}$), an automatic system associated with an YSI 6600 probe provided continuous and hourly measurement of different parameters in the water column (salinity, temperature, fluorescence and turbidity). Discrete measurements of salinity, dissolved oxygen (DO) and temperature were also made in each tank every morning (08:00) using a portable conductivity meter (WTW cond330i, Welheim, Germany) and an oxygen meter (WTW oxi330i, Welheim, Germany). Twice a week in the morning (08:00), tank water was sampled at $50 \mathrm{~cm}$ below the water surface using a 2-1 $\mathrm{HCl}$-rinsed black polyethylene bottle to monitor the phytoplankton communities and analyse various parameters including $\mathrm{pH}$, fluorescence, turbidity, nutrients and organic matter. Due to the shallowness of the tanks, this single water sample was representative of the entire water body, as tested in a preliminary experiment (unpublished data). 


\subsection{Laboratory analyses}

Immediately after water sampling, $\mathrm{pH}$, fluorescence, and turbidity were measured in subsamples using a pH meter WTW pH315i (Welheim, Germany) and an Aquafluor TM Handheld fluorometer (Turner Design, USA). Water samples were then filtered through the $0.7 \mu \mathrm{m}$ pore size GF/F Whatman filter and sub-sampled for the different analyses.

Chemical analyses. Ammonium $\left(\mathrm{NH}_{4}{ }^{+}\right)$and soluble reactive phosphorus (SRP) analyses were carried out immediately on fresh water samples, while the other nutrients were measured on frozen samples. Ammonium was analysed following the Grasshoff and Johannsen, (1972) method and SRP were measured in accordance with the molybdenum blue reaction described by Murphy and Riley (1962). Nitrate and nitrite $\left[\left(\mathrm{NO}_{2}{ }^{-}+\mathrm{NO}_{3}{ }^{-}\right)-\mathrm{N}\right](\mathrm{NOx})$, were determined using standard colorimetric techniques on a Bran + Luebbe AutoAnalyser III (Raimbault et al., 1990). Silicates were analysed only 5 times (d1, d11 d18, d25 and d39) during the experiment, as previously described by Mullin and Riley (1955). Dissolved organic nitrogen (DON) was analysed following oxidation procedure described by Raimbault et al. (1999). Pre-oxidation dissolved inorganic nitrogen (DIN) concentrations were subtracted from the post-oxidation total dissolved nitrogen (TDN) concentration to derive the DON concentrations.

Fluorometry. To analyse the Chlorophyll $a(\operatorname{chl} a)$ concentration in the water column, 25 to 50 $\mathrm{ml}$ water samples were filtered through Whatman $\mathrm{GF} / \mathrm{F}$ filters and then stored frozen $\left(-20^{\circ} \mathrm{C}\right)$ until they were analysed. Chlorophyll $a$ and pheophytin $a$ concentrations were determined in methanol extract before and after acidification using a fluorometer (Model TD700, Turner designs, Sunnyvale, CA, USA) using the method described by Herbland et al. (1985). 
Flow cytometry. Water column subsamples $(1.5 \mathrm{ml})$ were preserved with $1 \%$ Glutaraldehyde (final concentration) and stored in liquid nitrogen pending flow cytometric analysis (Vaulot et al., 1989). Samples were defrosted at ambient temperature and subsequently analysed using a FACSCan flow cytometer (BD-Biosciences, San Jose, CA) equipped with an air-cooled argon laser $(488 \mathrm{~nm}, 15 \mathrm{~mW})$. Methodology and data analysis used in this study are fully described in Lemonnier et al. (2016). Based on cellular RALS and fluorescence properties, several populations were conventionally distinguished (e.g. Lucas et al., 2010): two distinct Synechococcus populations and five eukaryotes groups. The two picocyanobacteria populations (Syn) were pooled in a single group.

Spectrofluorimetry. Water samples (0.2 1) were filtered onto $47 \mathrm{~mm} \mathrm{GF/F} \mathrm{filters} \mathrm{and} \mathrm{stored} \mathrm{at}$ $-80^{\circ} \mathrm{C}$ until analysis. Chlorophyll pigments were extracted in $95 \%$ acetone and analysed by spectrofluorometry with a Perkin Elmer LS55 spectrofluorometer following the method described in Neveux and Lantoine (1993), and using qualitative and quantitative improvements described in Ténorio et al. (2005) and Neveux et al. (2010). Determination of the different pigments was implemented from the $31 \times 26$ excitation-emission matrix (806 fluorescence data) by the PARAFAC method (Luciani et al., 2007) adapted for pigments by Chevalier (com. pers.). Concentrations (in $\mu \mathrm{g} \mathrm{l}^{-1}$ ) for chl $a$, chl $b$, chl $(c 1+c 2)$, chl $c 3$, divinylchl $a(\mathrm{dv}-\mathrm{chl} a)$ were estimated using external standards provided by DHI® Water and Environment (Denmark). Chlorophyll $a$ was used as proxy for phytoplankton bulk, and the other chlorophylls provided information on the composition of phytoplankton communities (Roy et al., 2011).

\subsection{Contribution of each taxa to Tchl $a$}

The chl $a$ associated with picocyanobacteria ( $c h l a_{\text {picoyano}}$ ) was estimated using FCM counts and a chl $a$ content of $0.94 \mathrm{pg}^{-1}$ cell $^{-1}$ (Lemonnier et al., 2016). The chl $a$ associated with 
chromophytes and green algae $\left(\operatorname{chl} a_{(\mathrm{c}+\mathrm{b})}\right)$ was calculated by subtracting the chl $a_{\text {picocyano }}$ from Tchl $a$. A strong correlation $(\mathrm{r}=0.99, \mathrm{n}=132)$ was observed between chl $a_{(\mathrm{c}+\mathrm{b})}$ and chl $\left(c_{1}+c_{2}\right)$ for samples containing less than $0.5 \mu \mathrm{g} \mathrm{l} \mathrm{l}^{-1}$ of chl $b$, leading to a mean chl $\left(c_{1}+c_{2}\right) / \mathrm{chl}$ $a_{(\mathrm{c}+\mathrm{b})}$ ratio of 0.183 (Fig. S1). Using this ratio and concentration of chl $\left(c_{1}+c_{2}\right)$, the chl $a$ associated with chromophytes $\left(\mathrm{chl} \mathrm{a}_{(\mathrm{c})}\right)$ was estimated in all the samples. Chlorophyll $a$ associated with diatoms and dinoflagellates chl $a_{(\text {(iat+dino) }}$ was calculated from chla (c) $_{\text {minus }}$ chl $a$ linked to cryptophytes and haptophytes. Since pelagophytes and chrysophytes have never or rarely been described in environments such as shrimp ponds in New Caledonia (Lemonnier et al., 2016), these taxa were not taken into account in our calculations. The contribution of haptophytes ( $\left.\operatorname{chl} a_{(\text {Hapto) }}\right)$ was calculated using a chl $c 3 / \mathrm{chl} a$ ratio of 0.161 recently found for shrimp ponds (Lemonnier et al., 2016), while chl $a$ associated with cryptophytes (chl $a_{(\text {Crypt })}$ ) was estimated using FCM counts and a chl $a$ content of 1.35 pg cell $^{-1}$ (Lafarga-De la Cruz et al., 2006; da Silva et al., 2009). Finally, the chl $a$ attributed to green algae chl $a_{\text {(chloro) }}$ was equal to $\operatorname{chl} a_{(\mathrm{c}+\mathrm{b})}$ minus $\operatorname{chl} a_{(\mathrm{c})}$, as calculated above.

\subsection{Water column metabolism and Daily $\mathrm{N}$ budget}

\subsubsection{Metabolism}

Oxygen fluxes in the water column were measured in light and dark incubation bottles. These bottles $(300 \mathrm{ml})$ were made of borosilicate glass and had been soaked in dilute HCI (1\% vol/vol) for several days before the measurements. The bottle were rinsed and filled with water taken from the tanks at $50 \mathrm{~cm}$ below the surface. Incubation was carried out in 8 tanks at mid-depth (two per treatment for D12 $\mathrm{S}^{+}, \mathrm{D} 12 \mathrm{~S}^{-}, \mathrm{D} 4 \mathrm{~S}^{+}$and $\mathrm{D} 4 \mathrm{~S}^{-}$). Oxygen sensor spot method was used to follow oxygen as described in Warkentin et al. (2007). SP-PST3-PSUPYOP-D5 oxygen sensor spots, also known as planar optodes (Presens GmbH, Regensburg, Germany), and a fibre-optic oxygen meter (Fibox 3: Presens GmbH) were used for this study. 
Oxygen fluxes were assessed from the time course of oxygen between 9 a.m. and 1 p.m. with a 1 hour time step. Total Respiration (R) and Net Primary Production (NPP) rates were deduced from the DO variations in the dark and light bottles respectively (Bender et al., 1987). Gross primary production (GPP) represented the sum of the rate of R and NPP:

GPP $\left(\mu \mathrm{molO} 21^{-1} h^{-1}\right)=\mathrm{R}+\mathrm{NPP}($ Eq. 1$)$

\subsubsection{Daily $\mathrm{N}$ budget}

To calculate the total phytoplankton $\mathrm{N}$ demand, a stoichiometry of 6.6 between daily GPP and daily phytoplankton N demand was used following Stumm and Morgan (1996):

$\mathrm{N}$ demand $\left(\mu \operatorname{molN~} 1^{-1}\right.$ day $\left.^{-1}\right)=($ GPP $\times 12) / 6.6($ Eq. 2$)$

We hypothesize that phytoplankton daily $\mathrm{N}$ demand was supported (1) by the $\mathrm{N}$ pool excreted by shrimp and (2) by the internal $\mathrm{N}$ pool produced through mineralization processes in the water column assuming that the nitrogen input by renewed water was negligible.

(1) Daily $\mathrm{N}$ input excreted by shrimp was derived from food, following Ebeling et al. (2006):

$$
\text { Daily } \mathrm{N} \text { input }\left(\mu \mathrm{mol} 1^{-1} \mathrm{day}^{-1}\right)=((\text { daily feed input } \times \mathrm{PC} \times 0.144) / 14) / \mathrm{V} \quad \text { (Eq. 3) }
$$

where daily feed input is in $\mu \mathrm{gN} \mathrm{m} \mathrm{may}^{-1}$, PC represents protein content in feed (45\% in this study) and V is the volume of the tank.

(2) Potential $\mathrm{N}$ mineralization $\left(\mathrm{N}_{\min }\right)$ was assessed using daily heterotrophic respiration $\left(\mathrm{R}_{\mathrm{het}}\right)$, deduced from total respiration (R) and corrected from phytoplankton basal respiration. Phytoplankton basal respiration was fixed at 20\% of daily GPP following Langdon (1993):

$$
\mathrm{R}_{\text {het }}\left(\mu \mathrm{mol} \mathrm{l}^{-1} \text { day }^{-1}\right)=\mathrm{R} \times 24-0.2 \times(\mathrm{GPP} \times 12) \quad(\text { Eq. 4) }
$$

Heterotrophic respiration was used to obtain the potential $\mathrm{N}$ mineralization following a stoichiometry of 6.6 between $\mathrm{O}_{2}$ consumption and $\mathrm{N}$ mineralization (Chapelle et al., 2000):

$$
\mathrm{N}_{\min }\left(\mu \mathrm{mol} 1^{-1} \text { day }^{-1}\right)=\mathrm{R}_{\text {het }} / 6.6 \quad \text { (Eq. 5) }
$$


Daily $\mathrm{N}$ budgets refer to the difference between the assimilation by phytoplankton and production by shrimp excretion and potential mineralization. A correction was applied to this budget to take into account of the daily water exchange (Eq 6).

Daily $\mathrm{N}$ budget $\left(\mu \mathrm{mol}{ }^{-1}\right.$ day $\left.^{-1}\right)=\left(\right.$ Daily $\mathrm{N}$ input $+\mathrm{N}_{\min }-\mathrm{N}$ demand $)-0.2 \times\left[\mathrm{NH}_{4}^{+}\right]$ (Eq. 6).

\subsection{Statistical analyses}

Results are presented as means \pm standard deviation (S.D.). Statistical comparisons of experimental data were carried out using XLStat software 2011 (Addinsoft, Paris, France), at each sampling date by a two-way analysis of variance (ANOVA), with shrimp density (D) (two or three fixed levels - function of the data set) and with or without access to the sediment (S) (2 fixed levels) as major sources of variance (Scherrer, 1984). Data were first checked for normal distribution and homogeneity of variance using the Shapiro-Wilk and Bartlett's tests, respectively. If data were not normally distributed, they were transformed for normality using log-transformation, square root or arcsine transforms. If data did not meet the test criteria after appropriate transformations, comparisons were made using the nonparametric Kruskal-Wallis test. Differences were considered significant for $\mathrm{p}<0.05$. For analysis, data were grouped within 2 periods according to climatic conditions: day 8 to 18 (period A) and day 29 to 43 (period B); mean values for each response variable in each mesocosm were calculated over each period. Mean data were transformed for normality and submitted to a repeated-measures analysis of variance model where period was the two-level repeated-measures variable and the treatments density and access to sediment were the two main factors. This procedure was used to explore major trends in the phytoplankton compartment over the entire course of the experiment. 


\section{Results}

\subsection{Survival and growth of shrimp}

Survival rates of shrimp at the end of the experiment ranged between 81 and $95 \%$ and were not significantly different between treatments (Table S1, two-way ANOVA test). Inversely, the final weight varied between treatments from $11.2 \pm 0.2,12.3 \pm 1.1,14.5 \pm 0.4$ and $16.1 \pm$ $0.5 \mathrm{~g}$ in D12S- D4S- D12S+ and $\mathrm{D}^{-} \mathrm{S}^{+}$respectively. The growth was significantly higher in thanks with low shrimp density (D4) and with access to sediment $\left(\mathrm{S}^{+}\right)$.

\subsection{Environmental conditions and physico-chemical parameters}

The experiment was marked by two significant periods (Fig. 1). The first period (A) was a dry and cool period with mean water temperature around $27^{\circ} \mathrm{C}$ and mean daily incident PAR around $650 \mu \mathrm{mol} \mathrm{m} \mathrm{m}^{-2} \mathrm{~s}^{-1}$. The second period (B) was rainy and hot, with a decrease of temperature at the end of the experiment. Rain fell almost continuously, with three peaks centred on days 29, 34 and 39. This period brought $161 \mathrm{~mm}$ of rain in two weeks, representing a mean dilution rate less than $2 \%$ of the water column per tank per day. Precipitation events were associated with mean daily PAR decreases down to $268 \mu \mathrm{mol} \mathrm{m} \mathrm{s}^{-2}$ 1. The salinity in tanks increased from 34.5 to 36.5 during period A and decreased thereafter, with minimum level (33.0) reached at the end of the experiment. Mean data in DO are presented figure 2a. Minimum mean value was $1.4 \mathrm{mg} \mathrm{l}^{-1}$. The results from the daily two way ANOVA show a significant effect of $\mathrm{D}(\mathrm{p}<0.05)$ from day 4 to the end of the experiment, with lower concentrations in treatments D12 (Fig. 2a). Significant changes in DO were also found in relation to $\mathrm{S}$, but only from day 22 to the end of the experiment. $\mathrm{S}^{+}$treatment showed higher values of DO than $\mathrm{S}^{-}$treatment. $\mathrm{pH}$ (Fig. S2) varied from 7.8 to 8.5 with a decrease from day 11 to day 22, followed by stabilization and then an increase during the last days. This trend was similar in all treatments, but the amplitude of variations changed with D and S, 
especially from day 15 and from day 22 to the end of the experiment (not significant at days 36 and 39). At each sampling date (except at day 1), turbidity was significantly different (Kruskal-Wallis test; $\mathrm{p}<0.05$ ) between treatments. Mean values ranged from 6.2 to 12.9 NTU and from 10.9 to 46.5 for D4S ${ }^{+}$and D12S ${ }^{+}$, respectively (Fig. 2b). Turbidity in the other treatments did not exceed 3.4 NTU. Note that in the D12S ${ }^{+}$, turbidity increased quickly after shrimp stocking, with a maximum (32 - 46 NTU) at day 8 , and decreased during the rainy period (B) to a minimum (11 NTU) at day 36.

\subsection{Nutrients $\left(\mathrm{NH}_{4}{ }^{+}, \mathrm{NOx}, \mathrm{SRP}\right)$ and $\mathrm{DON}$}

Ammonium concentration in tanks ranged from 0.0 to $16.8 \mu \mathrm{mol} \mathrm{l}^{-1}$. The daily two-way ANOVA show a significant effect of $\mathrm{S}$ on $\mathrm{NH}_{4}{ }^{+}$from $\mathrm{d} 22$ to the end of the experiment (except at d29 and d39), with lower concentrations in $\mathrm{S}^{+}$than in $\mathrm{S}^{-}$treatments (Fig. 2c). The effect of D was less evident and only occasionally significant, at days 4, 22 and 25 . NOx concentrations remained very low $\left(<0.3 \mu \mathrm{mol}^{-1}\right)$ except at the end of the experiment (days 32 and 39) in $\mathrm{S}^{-}$tanks (D4S $\mathrm{S}^{-}$and $\mathrm{D} 12 \mathrm{~S}^{-}$), with concentrations up to $1 \mu \mathrm{mol} \mathrm{l}^{-1}$ (Fig. 2d). Mean SRP concentrations (Fig. 2e) were below $0.1 \mu \mathrm{mol} \mathrm{l}^{-1}$ except in treatments with high stocking density (D12 $\mathrm{S}^{+}$and $\left.\mathrm{D} 12 \mathrm{~S}^{-}\right)$. These treatments showed values ranging from 0.02 to $0.38 \mu \mathrm{mol}$ $1^{-1}$ with maxima observed in the second period. Results show a significant positive D effect on SRP concentrations from day 8 to 22 and at day 36 (Fig. 2e). Conversely, access to the sediment (S) did not significantly change the SRP concentration in the water column. Silicate concentrations ranged from 0 to $35 \mu \mathrm{mol} \mathrm{l}^{-1}$. No significant effect of $\mathrm{S}$ and $\mathrm{D}$ on $\mathrm{Si}$ concentrations was shown. The daily repeated-measure ANOVA show a significant effect of period for $\mathrm{NH}_{4}{ }^{+}$and NOx but not for SRP (Table 1). The N/P ratio (mole/mole) increased from around 20 to values higher than 50 in treatments without shrimp and without access to sediment $\left({\mathrm{D} 0 \mathrm{~S}^{+}}^{+}, \mathrm{D} 0 \mathrm{~S}^{-}, \mathrm{D}_{4} \mathrm{~S}^{-}\right.$and $\left.\mathrm{D} 12 \mathrm{~S}^{-}\right)$, especially during the second period B (Table 2). In 
the other treatments, N/P values were generally $<50$, averaging $24 \pm 21$ and $26 \pm 15$ in D4S ${ }^{+}$ and $\mathrm{D} 12 \mathrm{~S}^{+}$, respectively. The $\mathrm{NH}_{4}{ }^{+} / \mathrm{NOx}$ ratio ranged from 0.2 to 40 (Table 2). The daily repeated-measure ANOVA show a significant effect of period for The $\mathrm{NH}_{4}{ }^{+} / \mathrm{NOx}$ ratio but not for the N/P ratio (Table 1).

After shrimp introduction, DON concentrations increased whatever the treatment (Fig. 2d). Significant effect of D was shown on daily mean concentrations from day 11. Concentrations were lower in $\mathrm{S}^{+}$than in $\mathrm{S}^{-}$treatments, but the difference was statistically significant only at days 11,25 and 32 . Highest DON values were found in the treatment D12S $\left(>35 \mu \mathrm{mol} \mathrm{l}^{-1}\right)$.

\subsection{Phytoplankton biomass}

Total chl $a$ exhibited the same patterns in all treatments containing shrimp, with an increase from day 4 to day 8 (Fig. 3). Moreover, it appeared that D and S both have a positive and significant impact on the Tchl $a$ concentrations even though the impact of S was visible 14 days after that of D. Tchl $a$ maxima were recorded in D12S $\mathrm{S}^{+}$treatment $\left(>15 \mu \mathrm{g}^{-1}\right)$ and the lowest values $\left(\sim 5 \mu \mathrm{g}^{-1}\right)$ in $\mathrm{D} 4 \mathrm{~S}^{-}$, when maximum values in $\mathrm{D} 4 \mathrm{~S}^{+}$and $\mathrm{D} 12 \mathrm{~S}^{-}$were similar and around $10 \mu \mathrm{g} \mathrm{l}^{-1}$. Comparatively, concentrations in control tanks (without shrimp) remained low $\left(<2 \mu \mathrm{g}^{-1}\right)$ and close to the initial concentrations $\left(0.63 \pm 0.68 \mu \mathrm{mol} \mathrm{l}^{-1}\right)$. Concentrations were not significantly different between periods A and B whatever the treatment (Table 3). Phaeophytin $a$ represented $20 \%$ to $57 \%$ of Tchl $a$. This ratio decreased during algae blooming at the beginning of the experiment (day 8 to day 15), and then increased toward the end. Increase of the ratio was higher in $\mathrm{S}^{-}$than in $\mathrm{S}^{+}$, but the effect of $\mathrm{S}$ was only significant at day 32 (not shown).

\subsection{Phytoplankton abundance and diversity}

3.5.1. Pico- and nanophytoplankton abundance by flow cytometry 


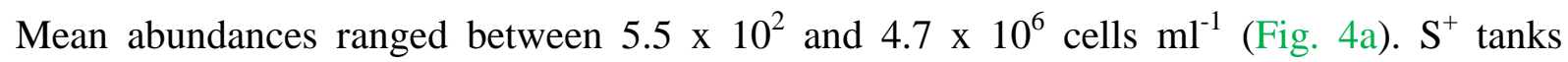
showed higher abundances than $\mathrm{S}^{-}$tanks from day 11. However, due to the high data variability, differences were significant $(\mathrm{p}<0.05)$ only at days 8,39 and 43 . Shrimp density effect on picocyanobacteria abundance was observable only for the last sampling date.

Among the eukaryotes, the smallest were assigned to picoeukaryotes (Peuk) and the largest to cryptophytes (Cry) (Courties et al., 2005; Lucas et al., 2010). To make the presentation of results easier, the three other eukaryote populations were pooled in a single group named nanophytoplankton (Nan). Mean abundances of Peuk ranged from 0 to $1.0 \times 10^{6}$ cells $\mathrm{ml}^{-1}$. They increased from day 11 in $\mathrm{S}^{+}$tanks (Fig. 4b) as did picocyanobacteria, but due to the high data variability, the effect of S was not statistically demonstrated. Likewise, no D effect was observed. Nanophytoplankton was amongst the less abundant groups, with abundances ranging between $0.3 \times 10^{3}$ to $3.0 \times 10^{5}$ cells ml $^{-1}$ (Fig. 4c). Maximum abundance was recorded in the treatment D12 $\mathrm{S}^{+} . \mathrm{S}$ did not show any significant effect except at day 22 with a positive effect. Abundances were significant with D at days 11, 22 and 39. Cryptophytes occurred in $85 \%$ of the samples, but their abundances (data not shown) were always lower than $70 \times 10^{3}$ cells $\mathrm{ml}^{-1}$. Factor D showed a significant positive effect at days 4, 15 and factor $\mathrm{S}$ a negative and positive effect at days 18 and 39, respectively.

\subsubsection{Pigment-based phytoplankton composition}

Chlorophyll $\left(c_{1}+c_{2}\right)$ quickly appeared in the water column just after shrimp stocking, with concentrations ranging from 0.07 to $5.08 \mu \mathrm{g}^{-1}$ (Fig. 5a). They were the main accessory pigments in all the treatments during the first period of the experiment (period A). However, the steady decrease of the $\operatorname{chl}\left(c_{1}+c_{2}\right) / \mathrm{Tchl} a$ ratio from 0.2 to 0.1 (data not shown) showed that the amount of these red-brown algae fell throughout the experiment, to the benefit of green algae and picocyanobacteria, whatever the treatment. Density factor regularly showed a 
significant positive effect on $\operatorname{chl}\left(c_{1}+c_{2}\right)$ concentrations. Values were generally higher in $\mathrm{S}^{+}$ than in $\mathrm{S}^{-}$cases (Fig. 5a), and a significant positive effect was observed at days 22 and 32. Note that silicates disappeared in relation with the increase of chl $\left(c_{1}+c_{2}\right)$ concentrations (Fig. 6), suggesting a high presence of diatoms in this group.

Chlorophyll $c_{3}$, which is present in Prymnesiophytes, Chrysophytes and Pelagophytes in addition to chl $\left(c_{1}+c_{2}\right)$, ranged from 0.00 to $0.52 \mu \mathrm{g} \mathrm{l}^{-1}$ (Fig. 5b). The daily two-way ANOVA regularly showed a positive and significant effect of D. Concentrations were generally and significantly higher in $\mathrm{S}^{+}$than in $\mathrm{S}^{-}$tanks. The chl $\mathrm{c}_{3} / \mathrm{Tchl} a$ ratio was generally low whatever the treatments $(<0.5)$. This ratio dropped throughout the experiment, indicating a progressive decrease of the proportion of these taxa within the phytoplankton community. No significant effect of S or D on this ratio (except at day 43) could be detected during the experiment. Chlorophyll $b$ can be used as a biomarker of green eukaryotes (Prasinophytes, Chlorophytes, Euglenophytes). Its concentration increased from day 15 and reached $8 \mu \mathrm{g} \mathrm{l}^{-1}$ at day 29 in $\mathrm{D} 12 \mathrm{~S}^{-}$(Fig 5c). It was significantly and positively affected by stocking density during the second part of the experiment. There was no significant effect of S. The chl $b / \mathrm{Tchl} a$ ratio increased from 0.0 to around 0.4 during the course of the experiment (data not shown), suggesting an increase of the proportion of green algae in the phytoplanktonic community.

\subsubsection{Contribution of each taxa to Tchl $a$}

Based on these estimates, Figure 7 shows the temporal variability of each group in terms of $\operatorname{chl} a$ in the different tanks. The chl $a$ linked to Cryptophytes was less than $1.2 \%$ of Tchl $a$, with $96 \%$ of the values $<0.5 \%$. Its contribution increased significantly between periods A and B (Table 3). Haptophytes were also a minor component of the phytoplankton biomass, representing less than $15 \%$ of Tchl $a$, but they were always detected in the samples. The contribution of picocyanobacteria to Tchl $a$ ranged from 0 to $31 \%$. With treatments $\mathrm{D}^{-} \mathrm{S}^{-}$and 
D12S', values never exceeded 6\%. The daily repeated-measure ANOVA show a significant effect of period, D and $\mathrm{S}$ of the contribution of picocyanobacteria on Tchl $a$ (Table 3). Proportions of chl $a$ associated to the (diatoms + dinoflagellates) group (chl $a_{\text {(diat+dino) }}$ ) decreased significantly between periods A and B whatever the treatment (Table 3), from $80 \%$ of Tchl $a$ at the beginning to $18 \%$ and $52 \%$ at the end. Green algae became the predominant contributor to Tchl $a$ in the second part of the experiment in all tanks (Table 3) and represented between 40 and $65 \%$ of Tchl $a$. The shift from diatoms + dinoflagellates to green algae coincided with the occurrence of the rainy period (Fig. 1a). When generating the chl $b$ versus chl $a_{\text {chloro }}$ scatter plot diagram, three distinct and strong correlations were observed (Fig. S3), leading to a mean chl $b / \mathrm{chl} a_{\text {chloro }}$ ratio of 0.61 (assemblage 1), 0.86 (assemblage 2) and 0.38 (assemblage 3). The three linear regressions were significantly different (ANCOVA; $\mathrm{F}=261 ; \mathrm{ddl}=3 ; \mathrm{p}<0.0001)$. Table 4 shows the distribution of these assemblages according to the treatment. Assemblage 1 was observed in all the treatments, assemblage 2 in the treatments with shrimp and without $S$, and assemblage 3 mainly in the treatments with shrimp and with S, suggesting an effect of D and S on the composition of the green algae community.

\subsection{Metabolism and $N$ budget}

Daily mean gross primary production (GPP) ranged from $5.1 \pm 3.3\left(\mathrm{D}^{-} \mathrm{S}^{-}\right)$to $21.2 \pm 9.6 \mu \mathrm{mol}$ $\mathrm{l}^{-1} \mathrm{~h}^{-1}\left(\mathrm{D} 12 \mathrm{~S}^{+}\right)$(Table 5). The daily two-way ANOVA show a significant positive effect of D on GPP at the end of the experiment and of $S$ at days 22, 25 and 43 (data not shown). Daily mean respiration rates ranged from $1.5 \pm 1.2$ to $5.7 \pm 1.9 \mu \mathrm{mol} \mathrm{l}^{-1} \mathrm{~h}^{-1}$ for $\mathrm{D} 4 \mathrm{~S}^{-}$and $\mathrm{D} 12 \mathrm{~S}^{+}$, respectively. Significant positive effects of D and S were also regularly shown on respiration from day 15 to the end of the experiment (data not shown).

For the $\mathrm{D} \mathrm{S}^{-}$treatment, phytoplankton $\mathrm{N}$ demand was more or less equal to the nutrient input by shrimp $\mathrm{N}$ excretion and $\mathrm{N}$ remineralization (Table 5). For $\mathrm{D} 4 \mathrm{~S}^{+}, \mathrm{N}$ demand of 
phytoplankton increased from around 10 to $25 \mu \mathrm{mol}^{-1}$ day $^{-1}$. The $\mathrm{N}$ budget decreased from $0.6 \pm 5.0 \mu \mathrm{mol} \mathrm{l}^{-1}$ day $^{-1}$ in $\mathrm{D} 4 \mathrm{~S}^{-}$to $-14.7 \pm 7.2 \mu \mathrm{mol} \mathrm{l}^{-1}$ day $^{-1}$ in $\mathrm{D} 4 \mathrm{~S}^{+}$, indicating a higher capacity of the bioturbated system to recycle mineral N. Results showed also that increasing densities implied an increase of potential $\mathrm{N}$ remineralization.

\section{Discussion}

\subsection{Effects of stocking densities and bioturbation on phytoplankton biomass}

Both stocking densities and bioturbation increased the phytoplankton biomass and microbial metabolism in our experiment. This result reveals the importance of these two factors in sustaining phytoplankton primary production in shrimp farm ponds with a soft bottom of sediment. Nevertheless, the pathways involved for each were not similar. Stocking density determined the amount of nutrients entering into the system, directly enlarging the nutrient pool available for primary production as already reported by several authors (e.g. Martin et al., 1998). This resulted in an increase in autotrophic plankton biomass in the D12 $\mathrm{S}^{-}$ treatment, reaching values 2.8-fold greater than in low shrimp density tanks (D4S ) and 9.1fold higher than in the tank without shrimp (D0S $\left.{ }^{-}\right)$. Likewise, bioturbation by shrimp increased phytoplankton biomass with values 2.3 -fold greater in $\mathrm{S}^{+}$than in $\mathrm{S}^{-}$tanks, as well as productivity for the same amount of nutrient entering into the system. Thus, the maximum biomass was recorded in $\mathrm{D} 12 \mathrm{~S}^{+}$treatments with Tchla concentrations averaging $30 \mu \mathrm{g} \mathrm{l}^{-1}$, a situation that is close to the biomass generally measured in earthen semi-intensive shrimp ponds in New Caledonia (Thomas et al., 2010; Pusceddu et al., 2011). The increase of water column respiration rates and the decrease of DON in $\mathrm{S}^{+}$treatment compared to $\mathrm{S}^{-}$suggest an increase of the organic matter mineralization rate in the water column as a consequence of sediment resuspension by bioturbation. This outcome could be explained by an intensification of bacterial production (BP) in the water column due to the increase of heterotrophic bacteria 
attached to sediment particles (e.g. Arfi and Bouvy, 1995). In shrimp ponds in New Caledonia, BP associated with particles ( $>3 \mu \mathrm{m}$ ) accounts for more than $80 \%$ of the total BP in the water column (unpublished data). The increase of mineralization rate theoretically implies more nutrients available for primary producers which may partly explain the significant and positive effect of bioturbation on primary production and phytoplankton biomasses. Resuspension of sediment was already reported to increase the mineralization rate by a factor between 2 and 5 in coastal sediments (Stahlberg et al., 2006). Thus, bioturbation appeared to be a key process for internal nutrient recycling in shrimp ponds. Another factor should be taken into account to explain the increase of Tchl $a$ in the water column in treatments with S: the effect of bioturbation on the microphythobenthos (MPB) resuspension. During this experiment, concentrations of Tchl $a$ in the first $\mathrm{cm}$ of the sediment ranged between 86 and $151 \mathrm{mg} \mathrm{m}^{-2}$ for $\mathrm{D} 12 \mathrm{~S}^{+}$and did not show any significant change with time (data not shown). These biomasses represented more than $80 \%$ of the primary producer biomass (phytoplankton and MPB) in the system. It is therefore assumed that MPB resuspension by shrimp could have a significant impact on Tchl $a$ measurements, as also suggested for shallow systems (Brito et al., 2012; Garstecki et al., 2002). The increase of turbidity in $\mathrm{D} 12 \mathrm{~S}^{+}$tanks between day 1 (before shrimp stocking) and day 4 (2 days after stocking) due to the resuspension of sediment by shrimp coincided with a small increase of phytoplankton biomass from 0.4 to $0.9 \mu \mathrm{g} \mathrm{l}^{-1}$. This preliminary result suggests a relatively limited effect of MPB on water column Tchl $a$ enrichment. However, further studies in shrimp pond ecosystems are needed to clarify this point.

\subsection{Limiting factors for phytoplankton growth}

Several limiting factors should be taken into account to understand phytoplankton dynamics in the different treatments. In the case of high density (D12) with and without S, the high 
turbidity due to bioturbation and/or high phytoplankton cell abundances led to a limited increase of GPP compared to biomass. This finding suggests that in this condition, photolimitation including self shading by phytoplankton could limit upper levels of GPP (Giovannini and Piedrahita, 1994). In a previous experiment conducted in the same tanks and similar zootechnical conditions, we showed a significant increase in photo-limitation of around $50 \%$ between surface and bottom. Because of this light limitation, it is likely that nutrient products from organic matter mineralization (SRP, $\mathrm{NH}_{4}{ }^{+}, \mathrm{NOx}$ ) were accumulated in the water column, as they are not efficiently utilized by phytoplankton. This situation mainly occurred in the second part of the experiment, when PAR values decreased due to cloudy/rainy conditions. In treatment $\mathrm{D} 12 \mathrm{~S}^{+}$, the negative effect of bioturbation on productivity of the system due to light limitation is probably mitigated by an increase of turbulent mixing. This process might favour the vertical displacement of phytoplankton to the surface and therefore it nutrient uptake capacity (MacIntyre, 1993). This possibility could explain why $\mathrm{NH}_{4}^{+}$accumulation was significantly lower in $\mathrm{D} 12 \mathrm{~S}^{+}$than in $\mathrm{D} 12 \mathrm{~S}^{-}$, except during bad weather conditions (day 29) when the light was too weak for primary productivity. Another limiting factor identified during this experiment was phosphorus. In $\mathrm{D}^{-\mathrm{S}^{-}}$and D0 treatment cases, the $\mathrm{N}: \mathrm{P}$ atomic ratio was far above the Redfield ratio of 16:1, which is required for optimal phytoplankton growth. Phosphorus depletion could limit GPP in the water column in these treatments assuming that nutrients were not in excess in the water column (Table 2). In $\mathrm{D}_{4} \mathrm{~S}^{+}$, the $\mathrm{N}: \mathrm{P}$ ratio was generally close to the Redfield ratio, suggesting that phytoplankton growth may not be theoretically limited by either $\mathrm{P}$ or $\mathrm{N}$.

To conclude, light which depends on weather, turbidity, cell abundance, depth and vertical mixing should be taking into account to understand phytoplankton dynamics in the shrimp pond ecosystem. A second factor is nutrient availability linked to feed input, which depends on the N/P ratio and the organic matter mineralization rate. With an increase of shrimp 
biomass and/or density, $\mathrm{P}$ becomes less limiting, while light becomes more and more limiting, implying a trend towards nutrient $\left(\mathrm{NH}_{4}{ }^{+}\right.$and $\left.\mathrm{NOx}\right)$ accumulation in the water column.

\subsection{Phytoplankton community dynamic and structure}

Shrimp stocking with the corresponding daily feed input triggered the onset of a phytoplankton bloom after 2 days. Growth dynamics of phytoplankton were typical, with an exponential increase, a short peak after 7 days followed by a decline of biomass (day 13) until the start of a new bloom. Apart from the change in the biomass, a shift in the phytoplankton assemblage was significant in all treatments. During period A, the increase of $\operatorname{chl}(c 1+c 2)$ in all tanks suggest that the group (diatoms + dinoflagellates) was dominant whatever the treatment. Note that the abundance of this group was positively correlated to the increase of shrimp stocking density, suggesting that diatoms and dinoflagellates were strongly favoured by eutrophication. The spectrofluorometry data failed to discriminate dinoflagellates from diatoms. In shrimp ponds, diatoms are often reported as a major component of phytoplankton biomass even though several studies, based on microscopic observations, suggest that dinoflagellates could become episodically dominant (Casé et al., 2008; Burford, 1997; Yusoff et al., 2002). In this environment characterized by high organic matter content, dinoflagellates are mostly heterotrophic (Garcés et al., 2006; Zapata et al., 2012). The organic matter content and the depletion of SRP in the water column in treatments characterized by high N/P ratio (Table 2) could be the factors promoting the dinoflagellates against diatoms during this first period (Yamamoto, 2003; Collos et al., 2009). Further confirmation with microscopic observations and/or molecular approaches are needed to understand the adaptive response of diatoms and dinoflagellates to eutrophication and to conclude on the dinoflagellates trophic regime in pond ecosystem. 
During period $\mathrm{B}$, the proportion of $\mathrm{chl}(c 1+c 2)$ decreased steadily and green algae (chlorophytes and prasinophytes) became dominant. Proliferation of tiny prasinophyceae belonging to the picoplankton and small nanophytoplankton was already observed in shrimp ponds in New Caledonia (Lemonnier et al., 2016) where they accounted for 10 to $53 \%$ of Tchl $a$ in the present study. Shift from diatoms to chlorophytes in coastal environment, which have been particularly subjected to eutrophication processes, are often described as the consequence of nitrogen pool change (e.g. Donald et al., 2011; Collos and Harrison, 2014; Glibert et al., 2016). The effects of change in the proportion of $\mathrm{NH}_{4}{ }^{+}$and $\mathrm{NOx}$ on assemblages were recently well illustrated and commented by Glibert et al. (2016). When $\mathrm{NH}_{4}{ }^{+}$is the dominant form (reduced form), flagellates, cyanobacteria and chlorophytes may proliferate while diatoms more likely dominate under $\mathrm{NO}_{3}$ enrichment conditions. Chlorophytes are not only physiologically better adapted to use $\mathrm{NH}_{4}{ }^{+}$but also more tolerant to toxic values than diatoms. In the present study, a significant effect of period on the $\mathrm{NH}_{4}{ }^{+} \mathrm{NOx}$ ratio was shown in the different treatments suggesting that $\mathrm{N}$ pool change could lead to a the shift from diatoms to chlorophytes. Several authors reported that diatom populations generally decrease in ponds due to silica depletion in the environment (Yusoff et al., 2002; Casé et al., 2008). However, this depletion was not observed in treatments without shrimp $\left({\mathrm{D} 0 \mathrm{~S}^{+}}^{+}\right.$and D0S $^{-}$), whereas the community shift did occur.

Beside the nutrient changes, $\mathrm{T}^{\circ}$ and light changes between period $\mathrm{A}$ and period $\mathrm{B}$ due to adverse weather conditions could also be implied in the shift from diatoms to chlorophytes observed in tanks. With an increase of $4^{\circ} \mathrm{C}$, temperature could enhance the effect of nutrients on phytoplankton community composition as reported in literature (e.g. Deng et al., 2014). The temperature increase could also increase the regenerated production and therefore modify the $\mathrm{N}$ pool, the production of $\mathrm{NH}_{4}{ }^{+}$favoring indirectly the observed shift. Beside the temperature, a possible effect of the light on the shift could also be suspected. Indeed, in our 
case, the change in phytoplankton populations appeared during the rainy period characterized by low radiation as also reported by Leruste et al. (2016) in hypertrophic shallow lagoons. The availability and quality of light are known to drive fluctuation in phytoplankton species (Huisman et al., 1999). Diatom abundance was increased by light fluctuations while cyanobacteria and green algae dominated at low and high constant conditions (Litchman, 1998). However, the community shift was similar in all treatments characterized by different turbidity levels.

Concerning the green algae community blooming mainly during period $\mathrm{B}$, three assemblages were distinguished according to their $\mathrm{chl} b / \mathrm{chl} a_{\text {chlorophytes }}$ ratios. Interestingly, the $\mathrm{chl} b / \mathrm{chl}$ $a_{\text {chlorophytes }}$ ratios calculated for each assemblage $(0.86 ; 0.61 ; 0.38)$ from spectrofluorometry data were close to those measured in a shrimp pond from HPLC data using CHEMTAX software, i.e. $0.81,0.65$, and 0.35 (Lemonnier et al., 2016). According to the authors, the ratio 0.81 was associated with Prasinophytes type 3 (with prasinoxanthin) and the ratio 0.65 with Prasinophytes type 1-2 (without prasinoxanthin) (Latasa et al., 2004). The ratio 0.35 identified as Chlorophytes by HPLC was slightly lower than the value found in our study $(0.38)$. Because Chlorophytes (assemblage 3) were more frequently observed in $\mathrm{S}^{+}$tanks than Prasinophytes (assemblages 1 and 2), we consider that this assemblage could be more efficient in an environment characterized by high nutrient recycling rate and high ammonium concentrations.

From $\mathrm{d} 11$ to the end of the experiment, the phytoplankton assemblage underwent another modification, with a major growth of picocyanobacteria in $\mathrm{S}^{+}$treatments. These treatments were characterized by an increase in nutrient recycling by the microbial loop, enriched with $\mathrm{NH}_{4}{ }^{+}$and urea from shrimp excretion and protein-rich feed given to cultured species (Burford and Williams, 2001). This finding was reported in various environments and by large scale manipulation experiments (e.g. Donald et al., 2011). In their review on this topic, Glibert et al 
(2016) reported that picocyanobacteria as well as chlorophytes (see above) may be physiologically better adapted to use reduced form of $\mathrm{N}$, mainly $\mathrm{NH}_{4}{ }^{+}$, than diatoms even if diatoms have a high nitrogen affinity, especially small-size species (Litchman et al., 2009). Indeed, these fast-growing prokaryotic algae as other small cells are known to be more efficient than larger cells in nutrient uptake (Agawin et al., 2004; Furnas et al., 2005). Because of their high surface to volume ratios, picocyanobacteria are able to use resources more efficiently than larger cells (Raven, 1998). The rising temperature from period A to period B could enhance the effect of ammonium on cyanobacterial biomass and dominance in the second period (O'Neil et al., 2012). As suggested by results from the $\mathrm{S}^{+}$treatments (Table 2), a low N:P molar ratio may also be a major factor favoring cyanobacteria dominance in aquaculture ponds (Paerl and Tucker, 1995). Several authors reported that abiotic factors, as salinity or turbidity, explained part of the variability in the diversity of marine Synechococcus populations in coastal waters (Jing et al., 2009; Liu et al., 2014). The next step should aim at investigating picocyanobacterial and more generally other taxonomic groups diversity in shrimp ponds, in order to better understand how shrimp pond environmental (nutrients, temperature and/or light) conditions might affect species-specific differences of this group.

To conclude on the phytoplankton community dynamic and structure, the differences between treatments remained limited whatever the period. This finding suggests high resilience of the phytoplankton community to feed input and bioturbation, and consequently to nutrient enrichment, $\mathrm{N}: \mathrm{P}$ ratio and turbidity in the shrimp pond ecosystem. Even if $\mathrm{N}$ pool was probably the main factor, data do not allow us to definitely conclude whether the shift from diatoms to chlorophytes observed in all treatments resulted either from the modification of $\mathrm{N}$ pool or from an external common factor $\left(\mathrm{T}^{\circ}\right.$, light). Further specific experiments are needed to define precisely the effect of each factor. 


\subsection{Importance of phytoplankton in maintaining the pond water quality}

DON is a major (30 - 40\%) component of the $\mathrm{N}$ waste produced during rearing and most of it is leached from the feed given to the reared shrimp (Burford and Williams 2001). In this experiment, the accumulation of DON in the water column with the highest feed inputs $\left(\mathrm{D} 12 \mathrm{~S}^{-}\right)$comparatively to lowest feed inputs $\left(\mathrm{D} 4 \mathrm{~S}^{-}\right)$suggested that DON production is higher than the recycling capacity of the system. Consequently, the dissolved vs particulate ratio increased in the water column with the increase of feed input. This organic matter enrichment directly impacted the stability of the system, in terms of daily $\mathrm{pH}$ and DO fluctuations. Indeed, the $\mathrm{pH}$ decrease observed in the water column in relation to feed input was likely linked to the increase in $\mathrm{CO}_{2}$ production through bacterial metabolism. This result suggests a substantial reduction in the acid-base buffering capacity of the system with increasing shrimp density and feed inputs. Conversely, supplied organic matter in the water column also stimulated respiration, which in turn caused depleted $\mathrm{O}_{2}$ in the morning. Based on the $\mathrm{N}$ daily budget calculations in the different tanks, it may also be shown that increasing stocking densities entailed an increase of phytoplankton $\mathrm{N}$ demand coupled with an increase of both of potential $\mathrm{N}$ mineralization and shrimp $\mathrm{N}$ excretion (Table 4). As a result, the turnover of $\mathrm{N}$ increased. As seen above, bioturbation by shrimps may favour organic matter mineralization by heterotrophic bacteria and then rapid nutrient uptake by phytoplankton, which limits the increase in the dissolved/particulate ratio. Because it improved the recycling of organic matter in the system by the microbial loop, bioturbation mitigated the accumulation of products (ammonia and nitrites) and the drop of DO and $\mathrm{pH}$ which are stressful parameters for shrimp (e.g. Lemonnier et al., 2004; Mugnier et al., 2008). The buffering capacity of the system to recycle $\mathrm{N}$ waste is however constrained by a threshold for the turnover of $\mathrm{N}$. Indeed, as presented in Fig. 8, $\mathrm{NH}_{4}{ }^{+}$accumulated in the water column when the $\mathrm{N}$ turnover rate exceeded $-10 \mu \mathrm{mol} \mathrm{l}^{-1}$ days $^{-1}$, while no accumulation was observed for a $\mathrm{N}$ turnover rate 
below this value. By limiting the primary production and consequently the uptake of $\mathrm{NH}_{4}{ }^{+}$, light is assumed to be the main factor limiting this recycling rate (see $\S 4.2$ ). To conclude on the importance of phytoplankton in maintaining the pond water quality, this compartment counterbalances "negative" effects of organic matter mineralization. However, this mitigation effect is governed by light availability in the system.

\subsection{Consequences for water column management}

The better understanding of the relative importance of food input and shrimp bioturbation in the phytoplankton dynamic could be useful for shrimp pond management. At low biomass, in our experiment, the system had strong resilience thanks to efficient nutrient recycling and to the robustness of primary production to the climatic condition changes linked to moderate turbidity. At higher density, the system became more unstable due to the greater sensitivity of primary production to light availability. By using fertilizers in shrimp ponds, we can reasonably hypothesize that increasing phytoplankton biomass would thus be inefficient in stabilizing the system and even might lead to a more unstable conditions. In that case, stability of the water column might be more efficient through carbon input, in order to stabilize the nutrient pool through heterotrophic assimilation and thus buffer system oscillations (Hari et al., 2004). This result partly explain the success of the Biofloc system sometimes used to stabilize the water column at high stocking density (Crab et al., 2012; Martínez-Córdova et al. (2015).

\section{Acknowledgements}

This work was supported by a research grant between the Loyalty Islands, Northern Province, Southern Province Government of New Caledonia and Institut Français de Recherche et d'Exploitation de la Mer (IFREMER) (12/1219969/C). The authors thank the anonymous 
reviewers for their useful comments and suggestions to improve the manuscript. We would

like to thank Aline Personne who kindly helped in the analysis.

\section{References}

Agawin, N.S.R, Duarte, C.M., Agustí, S., Vaqué, D., 2004. Effect of N:P ratios on response of Mediterranean picophytoplankton to experimental nutrient inputs. Aquatic Microbial Ecology 34 57-67.

Arfi, R., Bouvy, M., 1995. Size, composition and distribution of particles related to wind induced resuspension in a shallow tropical lagoon. Journal of Plankton Research 17, 557574.

Bender, M., Grande, K., Johnson, K., Marra, J., Williams, P.J.L., Sieburth, J., Pilson, M., Langdon, C., Hitchcock, G., Orchardo, J., Carleton, H., Donaghay, P., Heinemann, K., 1987. A Comparison of Four Methods for Determining Planktonic Community Production. Limnology and Oceanography 32, 1085-1098.

Bouwman, A.F., Beusen, A.H.W., Overbeek, C.C., Bureau, D.P., Pawlowski, M., Glibert, P.M., 2013. Hindcasts and Future Projections of Global Inland and Coastal Nitrogen and Phosphorus Loads Due to Finfish Aquaculture. Reviews in Fisheries Science 21, 112-156.

Brito, A.C., Fernandes, T.F., Newton, A., Facca, C., Tett, P., 2012. Does microphytobenthos resuspension influence phytoplankton in shallow systems? A comparison through a Fourier series analysis. Estuarine, Coastal and Shelf Science 110, 77-84.

Burford, M., 1997. Phytoplankton dynamics in shrimp ponds. Aquaculture Research 28, 351360.

Burford, M.A., Williams, K.C., 2001. The fate of nitrogenous waste from shrimp feeding. Aquaculture 198, 79-93.

Burford, M.A., Costanzo, S.D., Dennison, W.C., Jackson, C.J., Jones, A.B., McKinnon, A.D., Preston, N.P., Trott, L.A., 2003. A synthesis of dominant ecological processes in intensive shrimp ponds and adjacent coastal environments in NE Australia. Marine Pollution Bulletin 46, 1456-1469.

Casé, M., Leca, E.E., Leita, S.N., Sant'Anna, E.E., Schwamborn, R., Travassos de Moraes Junior, A., 2008. Plankton community as an indicator of water quality in tropical shrimp culture ponds. Marine Pollution Bulletin 56, 1343-1352.

Chapelle, A., Ménesguen, A., Deslous-Paoli, J-M., Souchu, P., Mazouni, N., Vaquer, A., Millet, B., 2000. Modeling nitrogen, primary production and oxygen in a Mediterranean lagoon. Impact of oysters farming and inputs from the watershed. Ecological Modelling, 127, 161-181.

Chen, C-C., Kemp, W.M., 2004. Periphyton communities in experimental marine ecosystems: scaling the effects of removal from container walls. Marine Ecology Progress Series 271, 27-41.

Cloern, J.E., 2001. Our evolving conceptual model of the coastal eutrophication problem. Marine Ecology Progress Series 210, 223-253.

Collos, Y., Bec, B., Jauzein, C., Abadie, E., Laugier, T., Lautier, J., Pastoureaud, A., Souchu, P., Vaquer, A., 2009. Oligotrophication and emergence of picocyanobacteria and a toxic dinoflagellate in Thau lagoon, southern France. Journal of sea research, 61, 68-75.

Collos, Y., Harrison, P.J., 2014. Acclimation and toxicity of high ammonium concentrations to unicellular algae. Marine Pollution Bulletin, 80, 8-23. 
Courties, C., Lemonnier, H., Herbland, A., 2005. Structure et évolution des peuplements picoplanctoniques de bassins aquacoles mesurés en cytométrie en flux lors des deux syndromes en Nouvelle Calédonie. In: Book of Abstract of "Ecosystèmes et crevetticulture en Nouvelle-Calédonie" (22 - 24 juin 2005) (ed IFREMER), Nouméa.

Crab, R., Defoirdt, T., Bossier, P., Verstraete, W., 2012. Biofloc technology in aquaculture: Beneficial effects and future challenges. Aquaculture, 356-357, 351-356.

da Silva, A.F., Lourenço, S.O., Chaloub, R.M., 2009. Effects of nitrogen starvation on the photosynthetic physiology of a tropical marine microalga Rhodomonas sp. (Cryptophyceae). Aquatic Botany, 91, 291-297.

De Schryver, P., Vadstein, O. 2014. Ecological theory as a foundation to control pathogenic invasion in aquaculture. International Society for Microbial Ecology Journal, 8, 23602368.

Deng, J., Qin, B., Paerl, H.W., Zhang, Y., Wu, P., Ma, J., Chen, Y., 2014. Effects of Nutrients, Temperature and Their Interactions on Spring Phytoplankton Community Succession in Lake Taihu, China. PLoS One, 9(12), e113960.

Donald, D.B., Bogard, M.J., Finlay, K., Leavitt, P.R., 2011. Comparative effects of urea, ammonium, and nitrate on phytoplankton abundance, community composition, and toxicity in hypereutrophic freshwaters. Limnology and Oceanography, 56, 2161-2175.

Ebeling, J.M., Timmons, M.B., Bisogni, J.J., 2006. Engineering analysis of the stoichiometry of photoautotrophic, autotrophic, and heterotrophic removal of ammonia-nitrogen in aquaculture systems. Aquaculture, 257, 346-358.

Furnas, M., Mitchell, A., Skuza, M., Brodie, J., 2005. In the other 90\%: phytoplankton responses to enhanced nutrient availability in the Great Barrier Reef Lagoon. Marine Pollution Bulletin 51, 253-265.

Garcés, E., Fernandez, M., Penna, A., Van Lenning, K., Gutierrez, A., Camp, J., Zapata, M., 2006. Characterization of NW Mediterranean Karlodinium spp. (Dinophyceae) strains using morphological, molecular, chemical, and physiological methodologies. Journal of Phycology 42, 1096-1112.

Garstecki, T., Wickham, S.A., Arndt, H., 2002. Effects of Experimental Sediment Resuspension on a Coastal Planktonic Microbial Food Web. Estuarine, Coastal and Shelf Science 55, 751-762.

Giovannini, P., Piedrahita, R.H., 1994. Modeling photosynthetic production optimization for aquaculture ponds. Aquacultural Engineering, 13, 83-100.

Glibert, P.M., Wilkerson, F.P., Dugdale, R.C., Raven, J.A., Dupont, C.L., Leavitt, P.R., Parker, A.E., Burkholder, J.M., Kana, T.M., 2016. Pluses and minuses of ammonium and nitrate uptake and assimilation by phytoplankton and implications for productivity and community composition, with emphasis on nitrogen-enriched conditions. Limnology and Oceanography, 61, 165-197.

Grasshoff, K., Johannsen, H., 1972. A New Sensitive and Direct Method for the Automatic Determination of Ammonia in Sea Water. ICES Journal of Marine Science 34, 516-521.

Hari, B., Madhusoodana Kurup, B., Varghese, J.T., Schrama, J.W., Verdegem, M.C.J., 2004. Effects of carbohydrate addition on production in extensive shrimp culture systems. Aquaculture, 241, 179-194.

Havens, K.E., 1991. Fish-induced sediment resuspension: effects on phytoplankton biomass and community structure in a shallow hypereutrophic lake. Journal of Plankton Research, 13 1163-1176.

Havens, K.E., 1993. Responses to experimental fish manipulations in a shallow, hypereutrophic lake: the relative importance of benthic nutrient recycling and trophic cascade. Hydrobiologia 254, 73-80. 
Heisler, J., Glibert, P.M., Burkholder, J.M., Anderson, D.M., Cochlan, W., Dennison, W.C., Dortch, Q., Gobler, C.J., Heil, C.A., Humphries, E., Lewitus, A., Magnien, R., Marshallm. H.G., Sellner, K., Stockwell, D.A., Stoecker, D.K., Suddleson, M., 2008. Eutrophication and harmful algal blooms: A scientific consensus. Harmful Algae 8, 3-13.

Herbland, A., Le Bouteiller, A., Raimbault, P., 1985. Size structure of phytoplankton biomass in the equatorial Atlantic Ocean. Deep Sea Research Part A. Oceanographic Research Papers 32, 819-836.

Huisman, J., Jonker, R.R., Zonneveld, C., Weissing, F.J., 1999. Competition for light between phytoplankton species: experimental tests of mechanistic theory. Ecology 80, 211-222.

Jing, H., Zhang, R., Pointing, S.B.P.B., Liu, H., Qian, P., 2009. Genetic diversity and temporal variation of the marine Synechococcus community in the subtropical coastal waters of Hong Kong. Canadian Journal of Microbiology 55, 311-318.

Joyni, M.J., Kurup, B.M., Avnimelech, Y., 2011. Bioturbation as a possible means for increasing production and improving pond soil characteristics in shrimp-fish brackish water ponds. Aquaculture 318, 464-470.

Lafarga-De la Cruz, F., Valenzuela-Espinoza, E., Millán-Núñez, R., Trees, C.C., Eduardo Santamaría-del-Ángela, E., Núñez-Cebrero, F., 2006. Nutrient uptake, chlorophyll a and carbon fixation by Rhodomonas sp. (Cryptophyceae) cultured at different irradiance and nutrient concentrations. Aquacultural Engineering, 35, 51-60.

Langdon, C., 1993. The significance of respiration in production measurements based on oxygen. ICES Mar. Sci. Symp., 197, pp. 69-78.

Latasa, M., Scharek, R., Gall, F.L., Guillou, L., 2004. Pigment suites and taxonomic groups in Prasinophyceae. Journal of Phycology, 40, 1149-1155.

Lemonnier, H., Bernard, E., Boglio, E., Goarant, C., Cochard, J-C., 2004. Influence of sediment characteristics on shrimp physiology: $\mathrm{pH}$ as principal effect. Aquaculture, 240, 297-312.

Lemonnier, H., Herbland, A., Salery, L., Soulard, B., 2006. "Summer syndrome" in Litopenaeus stylirostris grow out ponds in New Caledonia: Zootechnical and environmental factors. Aquaculture, 261, 1039-1047.

Lemonnier, H., Courties, C., Mugnier, C., Torréton, J-P., Herbland, A., 2010. Nutrient and microbial dynamics in eutrophying shrimp ponds affected or unaffected by vibriosis. Marine Pollution Bulletin 60, 402-411.

Lemonnier, H., Lantoine, F., Courties, C., Guillebault, D., Nézan, E., Chomérat, N., Escoubeyrou,, K., Galinié,, C., Blockmans, B., Thierry Laugier, T., 2016. Dynamics of phytoplankton communities in eutrophying tropical shrimp ponds affected by vibriosis. Marine Pollution Bulletin, 110, 449-459.

Leruste, A., Malet, N., Munaron, D., Derolez, V., Hatey, E., Collos, Y., De Wit, R., Bec, B., 2016. First steps of ecological restoration in Mediterranean lagoons: Shifts in phytoplankton communities. Estuarine, Coastal and Shelf Science, 180, 190-203.

Litchman, E., 1998. Population and community responses of phytoplankton to fluctuating light. Oecologia, 117, 247-257.

Litchman, E., Klausmeier, C.A., Yoshiyama, K., 2009. Contrasting size evolution in marine and freshwater diatoms. Proceedings of the National Academy of Sciences, 106, 26652670.

Liu, H., Jing, H., Wong, T.H.C., Chen, B., 2014 Co-occurrence of phycocyanin- and phycoerythrin-rich Synechococcus in subtropical estuarine and coastal waters of Hong Kong. Environmental Microbiology Reports 6, 90-99.

Lucas, R., Courties, C., Herbland, A., Goulletquer, P., Marteau, A.L., Lemonnier, H., 2010. Eutrophication in a tropical pond: Understanding the bacterioplankton and phytoplankton 
dynamics during a vibriosis outbreak using flow cytometric analyses. Aquaculture 310, 112-121.

Luciani, X., Mounier, S., Paraquetti, H.H.M., Redon, R., Lucas, Y., Bois, A., Lacerda, L.D., Raynaud, M., Ripert, M., 2007. Tracing of dissolved organic matter from the SEPETIBIA Bay (Brazil) by PARAFAC analysis of total luminescence matrices. Marine Environmental Research 65, 148-157.

Martin, J.L.M., Veran, Y., Guelorget, O., Pham, D., 1998. Shrimp rearing: stocking density, growth, impact on sediment, waste output; their relationships studied through the nitrogen budget in rearing ponds. Aquaculture 164, 135-149.

Martínez-Córdova, L.R., Emerenciano, M., Miranda-Baeza, A., Martínez-Porchas, M., 2015. Microbial-based systems for aquaculture of fish and shrimp: an updated review. Reviews in Aquaculture 7, 131-148.

McGlathery, K.J., Sundbäck, K., Anderson, I.C., 2007. Eutrophication in shallow coastal bays and lagoons: the role of plants in the coastal filter. Marine Ecology Progress series 348, 118.

MacIntyre, S., 1993. Vertical mixing in a shallow, eutrophic lake: Possible consequences for the light climate of phytoplankton. Limnology and Oceanography, 38, 798-817.

Mugnier, C., Zipper, E., Goarant, C., Lemonnier, H., 2008. Combined effect of exposure to ammonia and hypoxia on the blue shrimp Litopenaeus stylirostris survival and physiological response in relation to molt stage. Aquaculture, 274, 398-407.

Mullin, J.B., Riley, J.P., 1955. The spectrophotometric determination of silicate-silicon in natural waters with special reference to sea water. Analytica Chimica Acta 12, 162-170.

Murphy, J., Riley, J.P., 1962. A modified single solution method for the determination of phosphate in natural waters. Analytica Chimica Acta 27, 31-36.

Neveux, J., Lantoine, F., 1993. Spectrofluorometric assay of chlorophylls and phaeopigments using the least squares approximation technique. Deep Sea Research Part I: Oceanographic Research Papers 40, 1747-1765.

Neveux, J., Lefebvre, J-P., Le Gendre, R., Dupouy, C., Gallois, F., Courties, C., Gérard, P., Fernandez, J-M., Ouillon, S., 2010. Phytoplankton dynamics in the southern New Caledonian lagoon during a southeast trade wind event. Journal of Marine Systems 82, 230-244.

Nogales, B., Lanfranconi, M.P., Piña-Villalonga, J.M., Bosch, R., 2011. Anthropogenic perturbations in marine microbial communities. FEMS Microbiology Reviews 35, 275298.

O'Neil, J., Davis, T., Burford, M., Gobler, C., 2012. The rise of harmful cyanobacteria blooms: the potential roles of eutrophication and climate change. Harmful Algae 14: 312334.

Paerl, H.W., Tucker, C.S., 1995. Ecology of Blue Algae in Aquaculture Ponds. Journal of the World Aquaculture Society 26(2), 109-131.

Paerl, H.W., Otten, T.G., 2013. Harmful Cyanobacterial Blooms: Causes, Consequences, and Controls. Microbial Ecology 65, 995-1010.

Porter, E.T., Mason, R.P., Sanford, L.P., 2010. Effect of tidal resuspension on benthic-pelagic coupling in an experimental ecosystem study. Marine Ecology Progress series 413, 33-53.

Pusceddu, A., Della Patrona, L., Beliaeff, B., 2011. Trophic status of earthen ponds used for semi-intensive shrimp (Litopenaeus stylirostris, Stimpson, 1874) farming in New Caledonia (Pacific Ocean). Marine Environmental Research 72, 160-171.

Raimbault, P., Pouvesle, W., Diaz, F., Garcia, N., Sempéré, R., 1999. Wet-oxidation and automated colorimetry for simultaneous determination of organic carbon, nitrogen and phosphorus dissolved in seawater. Marine Chemistry 66, 161-169. 
Raimbault, P., Slawyk, G., Coste, B., Fry, J., 1990. Feasibility of using an automated colorimetric procedure for the determination of seawater nitrate in the 0 to $100 \mathrm{nM}$ range: Examples from field and culture. Marine biology 104, 347-351.

Raven, J.A., 1998. The twelfth Tansley Lecture. Small is beautiful: the picophytoplankton. Functional Ecology 12, 503-513.

Ritvo, G., Kochba, M., Avnimelech, Y., 2004. The effects of common carp bioturbation on fish pond bottom soil. Aquaculture 242, 345-356.

Ritvo, G., Neill, W.H., Lawrence, A.L., Samocha, T.M., 1997. Turbidity related to shrimp size in tanks with soil substrate. Aquacultural engineering 16, 221-225.

Rochelle-Newall, E.J., Chu, V.T., Pringault, O., Amouroux, D., Arfi, R., Bettarel, Y., Bouvier, T., Bouvier, C., Got, P., Nguyen, T.M.H., Mari, X., Navarro, P., Duong, T.N., Cao, T.T.T., Pham, T.T., Ouillon, S., Torréton, J.P., 2011. Phytoplankton distribution and productivity in a highly turbid, tropical coastal system (Bach Dang Estuary, Vietnam). Marine Pollution Bulletin, 62, 2317-2329.

Roy S, Llewellyn C, Egeland ES, Johnsen G (2011) Phytoplankton pigments. (ed Suzanna Roy CL, Einar Skarstad Egeland, Geir Johnsen). cambridge university press, Cambridge, pp. 845.

Scherrer, B., 1984. Biostatistique, Gaëtan Morin, Montréal (Québec), Canada. 850 pp.

Schmoker, C., Russo, F., Drillet, G., Trottet, A., Mahjoub, M-S., Hsiao, S-H., Larsen, O., Tun, K., Calbet, A., 2016. Effects of eutrophication on the planktonic food web dynamics of marine coastal ecosystems: The case study of two tropical inlets. Marine Environmental Research 119, 176-188.

Stahlberg, C., Bastviken, D., Svensson, B.H., Rahm, H., 2006. Mineralisation of organic matter in coastal sediments at different frequency and duration of resuspension. Estuarine, Coastal and Shelf Science 70, 317-325.

Stumm, W., Morgan, J.J., 1996. Aquatic Chemistry, Chemical Equilibria and Rates in Natural Waters, 3rd ed. John Wiley \& Sons, Inc., New York, 1022p.

Tenório, M.M.B., Le Borgne, R., Rodier, M., Neveux, J., 2005. The impact of terrigeneous inputs on the Bay of Ouinné (New Caledonia) phytoplankton communities: A spectrofluorometric and microscopic approach. Estuarine, Coastal and Shelf Science, 64, 531-545.

Thomas, Y., Courties, C., El Helwe, Y., Herbland, A., Lemonnier, H., 2010. Spatial and temporal extension of eutrophication associated with shrimp farm wastewater discharges in the New Caledonian Lagoon. Marine Pollution Bulletin 61, 387-398.

Vaulot, D., Courties, C., Partensky, F., 1989. A simple method to preserve oceanic phytoplankton for flow cytometric analyses. Cytometry 10, 629-635.

Warkentin, M., Freese, H.M., Karsten, U., Schumann, R., 2007. New and Fast Method To Quantify Respiration Rates of Bacterial and Plankton Communities in Freshwater Ecosystems by Using Optical Oxygen Sensor Spots. Applied and Environmental Microbiology 73, 6722-6729.

Yamamoto, T., 2003. The Seto Inland Sea - eutrophic or oligotrophic? Marine Pollution Bulletin, 47, 37-42.

Yusoff, F.M., Zubaidah, M.S., Matias, H.B., Kwan, T.S., 2002. Phytoplankton succession in intensive marine shrimp culture pond treated with a commercial bacterial product. Aquaculture Research 33, 269-278.

Zapata, M., Fraga, S., Rodríguez, F., Garrido, J., 2012. Pigment-based chloroplast types in dinoflagellates. Marine Ecology Progress series 465, 33-52. 
Table 1: F values from repeated-measured ANOVA for nutrients. Significant results are highlighted by asterisks.

\begin{tabular}{llllll}
\hline Treatment & $\mathrm{NH}_{4}{ }^{+}$ & $\mathrm{NO}_{\mathrm{x}}$ & $\mathrm{SRP}$ & $\mathrm{N} / \mathrm{P}$ & $\mathrm{NH}_{4}{ }^{+} / \mathrm{NO}_{\mathrm{x}}$ \\
\hline $\mathrm{D}(1)$ & $6.769^{*}$ & 0.001 & $99.383^{* * * *}$ & $14.212^{* * *}$ & $4.425^{*}$ \\
$\mathrm{~S}(2)$ & $5.383^{*}$ & $11.525^{* * *}$ & 0.532 & 1.333 & 0.190 \\
Period (3) & $9.204 * *$ & $48.545^{* * *}$ & 0.334 & 1.392 & $20.676^{* * *}$ \\
$1 \times 2$ & $5.467 *$ & $5.482^{*}$ & 1.777 & $13.597 * * *$ & 0.316 \\
$1 \times 3$ & 0.076 & 0.206 & 2.390 & 1.725 & 0.775 \\
$2 \times 3$ & $7.863 *$ & $16.746^{* * *}$ & 2.177 & 0.246 & 0.117 \\
$1 \times 2 \times 3$ & $4.406^{*}$ & $4.539 * *$ & 0.403 & $9.449 * * *$ & 0.356 \\
\hline$* \mathrm{p}<0.05 ; * * \mathrm{p}<0.01 ; * * * \mathrm{p}<0.001$ & & & &
\end{tabular}


Table 2: Temporal variability of N/P (mole/mole) ratio and $\mathrm{NH}_{4}{ }^{+} / \mathrm{NOx}$ ratio in the different treatments. $\mathrm{N}$ refers to ammonium $+\mathrm{NOx}$

\begin{tabular}{|c|c|c|c|c|c|c|c|}
\hline & \multirow[b]{2}{*}{ Days } & \multicolumn{3}{|c|}{ Period A } & \multirow[b]{2}{*}{25} & \multicolumn{2}{|c|}{ Period B } \\
\hline & & 1 & 11 & 18 & & 32 & 39 \\
\hline \multirow[t]{6}{*}{$N / P$} & DOS $^{-}$ & 22 & 16 & 34 & $>50$ & $>50$ & $>50$ \\
\hline & ${\mathrm{D} 0 \mathrm{~S}^{+}}^{+}$ & 19 & $>50$ & $>50$ & $>50$ & $>50$ & $>50$ \\
\hline & $\mathrm{D}^{2} \mathrm{~S}^{-}$ & $>50$ & 19 & $>50$ & $>50$ & $>50$ & $>50$ \\
\hline & D12S- & 16 & 16 & 23 & $>50$ & $>50$ & 44 \\
\hline & $\mathrm{D} 4 \mathrm{~S}^{+}$ & $>50$ & 9 & 16 & 23 & 17 & 13 \\
\hline & D12S ${ }^{+}$ & 35 & 12 & 7 & 26 & 47 & 28 \\
\hline \multirow[t]{6}{*}{$\mathrm{NH}_{4}^{+} / \mathrm{NOx}$} & DOS $^{-}$ & 10 & 17 & 2 & 2 & 2 & 1 \\
\hline & ${\mathrm{D} 0 \mathrm{~S}^{+}}^{+}$ & 8 & 4 & 11 & 7 & 3 & 1 \\
\hline & $\mathrm{D}_{4} \mathrm{~S}^{-}$ & 18 & 5 & 6 & 9 & 3 & 1 \\
\hline & D12S- & 6 & 15 & 17 & 30 & 10 & 3 \\
\hline & $\mathrm{D}_{4} \mathrm{~S}^{+}$ & 5 & 8 & 1 & 2 & 3 & 0 \\
\hline & D12S ${ }^{+}$ & 6 & 40 & 6 & 18 & 9 & 3 \\
\hline
\end{tabular}


1 Table 3: F values from Repeated-Measures ANOVA for concentration of total chl $a$ (Tchl $a$ )

2 and contribution of each algae group to chl $a$. Significant results are highlighted by asterisks.

\begin{tabular}{lllllll}
\hline Treatment & Tchl $a$ & Diat + Dino & Chloro & Picocyano & Hapto & Crypt \\
\hline $\mathrm{D}(1)$ & $148.871^{* * *}$ & 0.502 & 1.943 & $4.150^{*}$ & $9.701^{* * *}$ & 2.046 \\
$\mathrm{~S}(2)$ & $16.910^{* *}$ & 0.007 & 3.420 & $9.181^{*}$ & 0.020 & 0.642 \\
Period (3) & 1.229 & $72.576^{* * *}$ & $115.796^{* * *}$ & $16.926^{* * *}$ & 1.306 & $8.847^{* * *}$ \\
$1 \times 2$ & $4.525^{*}$ & 2.351 & $4.429^{*}$ & 2.579 & 1.385 & 3.554 \\
$1 \times 3$ & 0.516 & 3.092 & 3.255 & $3.913^{*}$ & 0.472 & 0.466 \\
$2 \times 3$ & 4.139 & 0.469 & $7.276^{*}$ & $5.637^{*}$ & 0.035 & 0.114 \\
$1 \times 2 \times 3$ & 1.236 & $3.890^{*}$ & $5.024^{* *}$ & $4.156^{*}$ & 0.219 & 1.597
\end{tabular}


5 Table 4: Green algae assemblages identified in each tank at each sampling date and distinguished by treatment. Data indicate chl $b$ 6 concentrations in $\mu \mathrm{g} \mathrm{l}^{-1}$.

Assemblage $1 \quad$ Assemblage 2

Assemblage 3

\begin{tabular}{|c|c|c|c|c|c|c|c|c|c|c|c|c|c|c|c|c|}
\hline \multirow{2}{*}{$\begin{array}{c}\text { Treatments } \\
\text { Time / Tank numbers }\end{array}$} & \multirow{2}{*}{\multicolumn{2}{|c|}{$\begin{array}{cc}\text { D0S- } & \text { D0S- } \\
1606 & 1612 \\
\end{array}$}} & \multirow{2}{*}{\multicolumn{2}{|c|}{\begin{tabular}{cc|} 
D0S+ & D0S+ \\
1614 & 1616 \\
\end{tabular}}} & \multirow{2}{*}{$\begin{array}{c}\mathrm{D} 4 \mathrm{~S}- \\
1601 \\
\end{array}$} & \multirow{2}{*}{\multicolumn{2}{|c|}{$\begin{array}{cc}\text { D4S- } & \text { D4S- } \\
1604 & 1611 \\
\end{array}$}} & \multicolumn{3}{|c|}{ D12S- D12S- D12S- } & \multicolumn{3}{|c|}{$\mathrm{D} 4 \mathrm{~S}+\mathrm{D} 4 \mathrm{~S}+\mathrm{D} 4 \mathrm{~S}+$} & \multicolumn{3}{|c|}{$\mathrm{D} 12 \mathrm{~S}+\mathrm{D} 12 \mathrm{~S}+\mathrm{D} 12 \mathrm{~S}+$} \\
\hline & & & & & & & & 1607 & 1608 & 1609 & 1603 & 1610 & 1615 & 1602 & 1605 & 1613 \\
\hline 1 & 0.03 & & 0.01 & 0.04 & 0.04 & 0.04 & 0.04 & 0.05 & 0.04 & 0.02 & 0.01 & 0.03 & 0.04 & 0.05 & 0.03 & 0.06 \\
\hline 4 & 0.01 & & & 0.02 & & 0.02 & 0.01 & 0.01 & 0.01 & 0.01 & & & & & & \\
\hline 8 & 0.11 & & 0.11 & 0.08 & & & & & & & & 0.09 & & 0.11 & & \\
\hline 11 & 0.03 & & 0.06 & 0.05 & & & & & 0.08 & & & & 0.24 & & & \\
\hline 15 & 0.07 & 0.01 & 0.03 & 0.03 & 0.04 & & & 0.58 & & 0.23 & & 0.07 & & & & \\
\hline 18 & 0.10 & & 0.08 & 0.03 & 0.17 & & 0.23 & 1.79 & 0.53 & 1.76 & & 0.39 & & 3.71 & & \\
\hline 22 & 0.18 & 0.04 & 0.10 & 0.41 & 2.44 & 0.02 & 1.33 & 0.28 & 1.8 & 1.9 & 0.14 & 2.79 & & 10.01 & 0.94 & \\
\hline 25 & 0.09 & 0.05 & 0.14 & 0.36 & 0.03 & 0.07 & 1.82 & 0.17 & 5.49 & 0.14 & 1,00 & 3.97 & & 8.4 & 3.13 & \\
\hline 29 & 0.08 & 0.18 & 0.13 & 0.18 & 0.13 & 1.59 & 2.46 & 4.28 & 16.52 & 2.05 & 1.57 & 4.44 & & 1.62 & & \\
\hline 32 & 0.36 & 0.21 & 0.19 & 0.37 & 0.91 & 3.14 & 1.25 & 5.34 & 4.29 & 12.87 & 3.16 & 0.79 & 0.5 & & & \\
\hline 36 & 0.44 & 0.35 & 0.22 & 0.25 & 0.28 & 0.12 & 0.41 & 0.95 & 3.35 & 11.35 & 3.66 & 1.11 & 1.82 & 2.89 & 0.01 & 0.32 \\
\hline 43 & 0.29 & 0.55 & 0.25 & 0.60 & 0.15 & 0.44 & 2.39 & 16.32 & 0.94 & 1.6 & 4.01 & 4.74 & 3.57 & 8.16 & 1.56 & 6.68 \\
\hline
\end{tabular}

Empty cells: no chl $b$. Green algae assemblage in samples containing less than $0.4 \mu \mathrm{g} \mathrm{l}^{-1}$ of chlorophyll $b$ were not able to be identified. 
Table 5: Metabolic rates and daily $\mathrm{N}$ budget $\left(\mu \mathrm{mol} \mathrm{l}^{-1} \mathrm{~h}^{-1}\right)$ in the different treatments. Mean \pm $\mathrm{SD}(\mathrm{n}=13)$

\begin{tabular}{|c|c|c|c|c|}
\hline & $\mathrm{D}^{2} \mathrm{~S}^{-}$ & $\mathrm{D} 4 \mathrm{~S}^{+}$ & ${\mathrm{D} 12 \mathrm{~S}^{-}}^{-}$ & ${\mathrm{D} 12 \mathrm{~S}^{+}}^{+}$ \\
\hline \multirow[t]{2}{*}{ GPP } & $5.1 \pm 3.3$ & $12.4 \pm 5.1$ & $10.2 \pm 5.5$ & $21.2 \pm 9.6$ \\
\hline & $(2.0-13.0)$ & $(3.1-20.2)$ & $(1.4-19.0)$ & $(6.1-38.6)$ \\
\hline \multirow[t]{2}{*}{ Respiration rates } & $1.5 \pm 1.2$ & $2.4 \pm 0.9$ & $2.8 \pm 1.3$ & $5.7 \pm 1.9$ \\
\hline & $(0.3-4.3)$ & $(0.5-3.3)$ & $(0.2-4.8)$ & $(3.1-8.4)$ \\
\hline Phytoplankton $\mathrm{N}$ demand & $-9.8 \pm 6.7$ & $-25.7 \pm 10.1$ & $-20.0 \pm 11.1$ & $-38.4 \pm 20.4$ \\
\hline Potential $\mathrm{N}$ mineralisation & $3.9 \pm 3.4$ & $4.9 \pm 2.0$ & $7.2 \pm 4.0$ & $12.9 \pm 7.8$ \\
\hline Shrimp N excretion & $6.5 \pm 0.4$ & $6.5 \pm 0.6$ & $19.5 \pm 1.3$ & $19.5 \pm 1.3$ \\
\hline Daily N budget & $0.6 \pm 5.0$ & $-14.2 \pm 7.2$ & $6.6 \pm 8.8$ & $-6.0 \pm 19.5$ \\
\hline
\end{tabular}



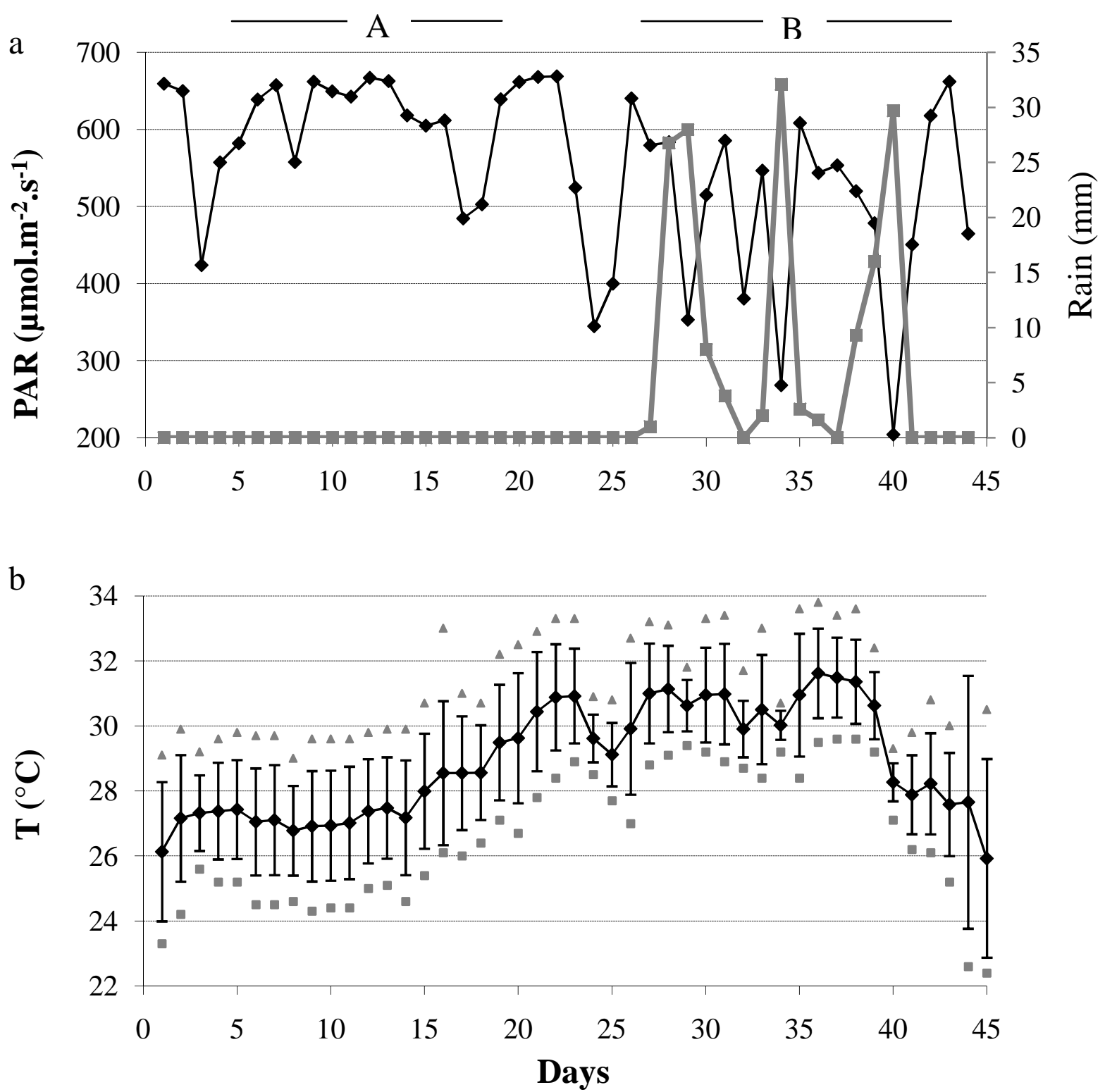

Fig. 1. (a) Temporal variations of daily rainfall (squares) and mean daily photosynthetic active radiations PAR (diamonds). A and $\mathrm{B}$ refer to dry and rainy periods. (b) Temporal variations of daily mean temperature $(\mathrm{N}=24$; diamonds). Squares and triangles represent the daily minimum and maximum values. 

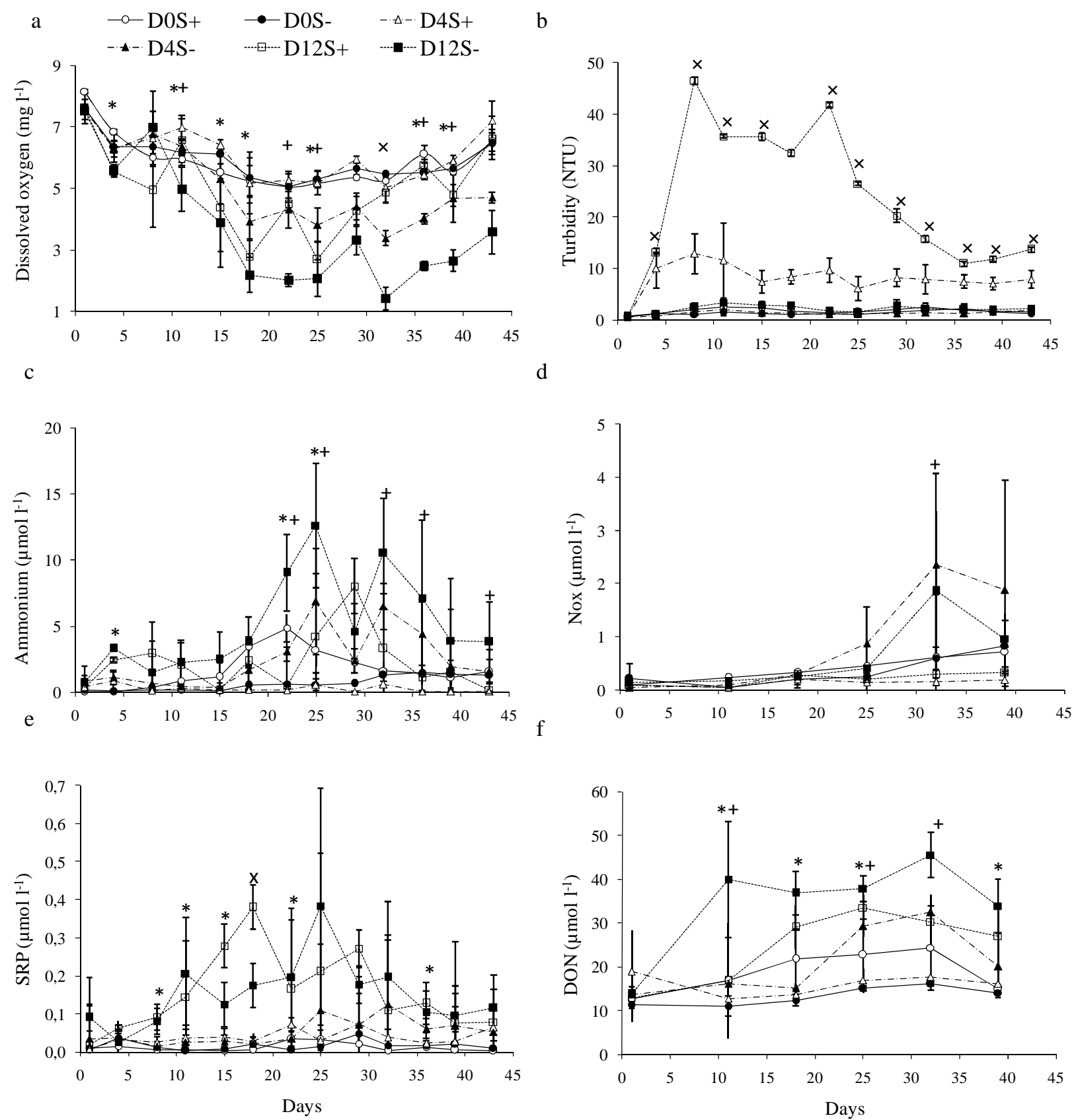

Fig. 2: Temporal mean $( \pm$ S.D.) variations of (a) dissolved oxygen, (b) turbidity, (c) ammonium, (d) nitrates and nitrites (NOx), (e) soluble reactive phosphorus (SRP) and (f) dissolved organic nitrogen $(\mathrm{DON})$ in the different treatments. Values are means $( \pm$ S.D. $)$ of three $\left(\mathrm{D} 4 \mathrm{~S}^{-;} \mathrm{D} 4 \mathrm{~S}^{+} ; \mathrm{D} 12 \mathrm{~S}^{-}\right.$and $\left.\mathrm{D} 12 \mathrm{~S}^{+}\right)$or two $\left(\mathrm{D}^{-} \mathrm{S}^{-}\right.$and $\left.\mathrm{D}^{+} \mathrm{S}^{+}\right)$replicate tanks per sampling time in each treatment. Signs $\left(^{*}\right)$ and $(+)$ indicate a significant density and access to sediment effects ( $\mathrm{p}<0.05)$, respectively (using two-way analysis of variance). Sign (x) indicate significant differences $(\mathrm{p}<0.05)$ between the daily values (using the Kruskal-Wallis test). 


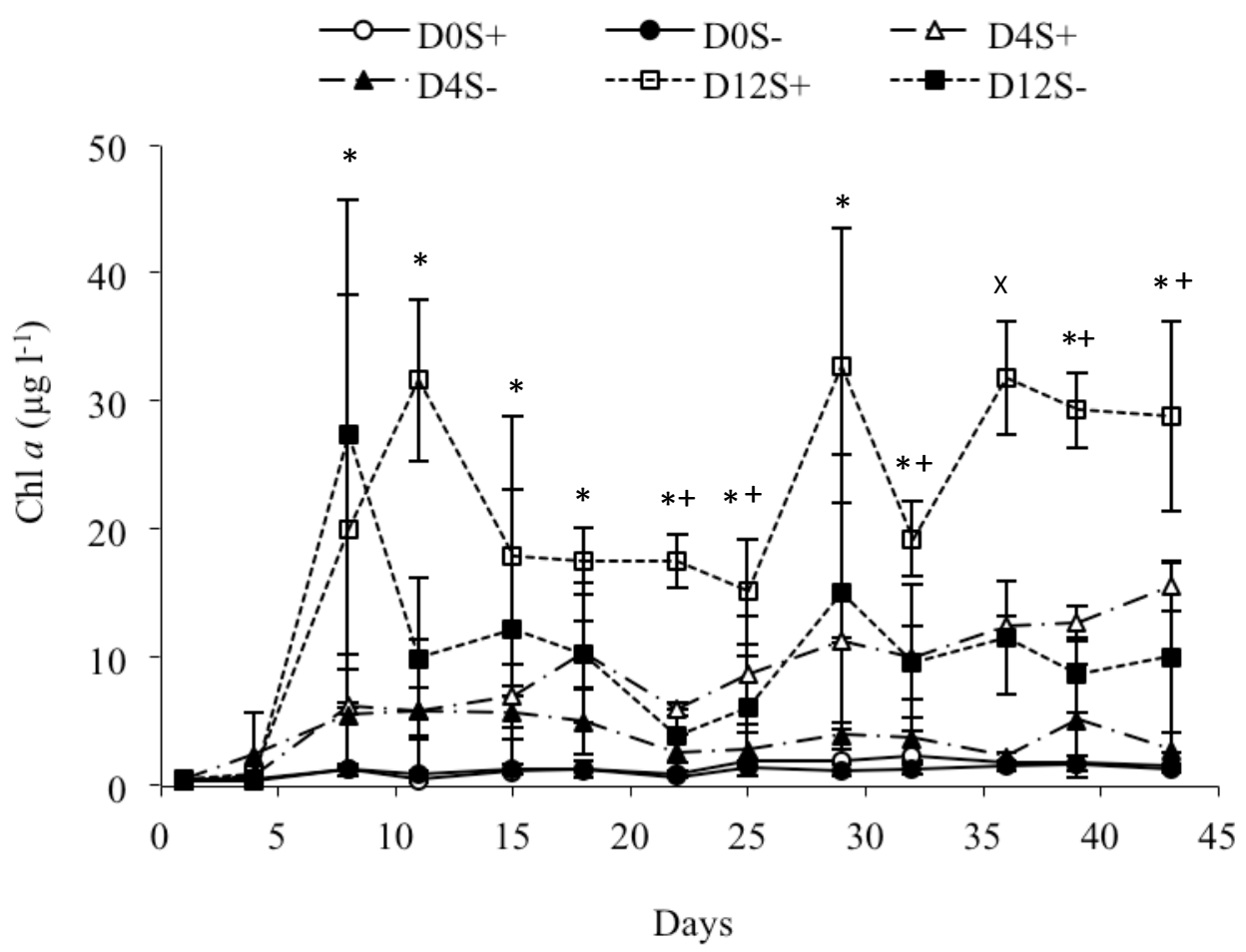

Fig. 3: Temporal mean $( \pm$ S.D. $)$ variations of chlorophyll $a$ concentrations in the different treatments. Signs $(*)$ and $(+)$ indicate a significant density and access to sediment effects $(\mathrm{p}<$ 0.05), respectively (using two-way analysis of variance). Sign (x) indicate significant differences $(\mathrm{p}<0.05)$ between the daily values (using the Kruskal-Wallis test). 

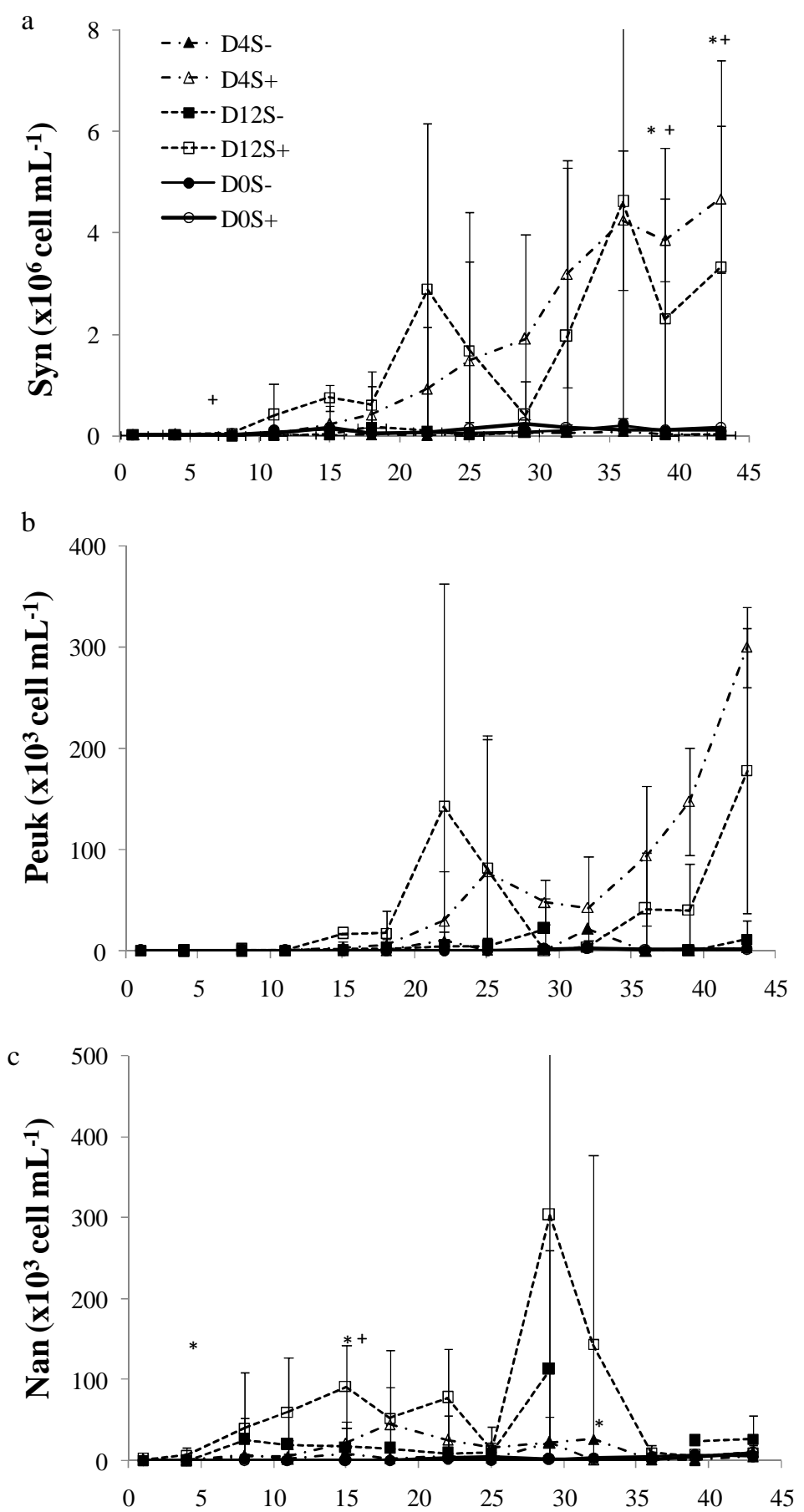

Fig. 4: Temporal mean ( \pm S.D.) variations of abundance of (a) picocyanobacteria (Syn), (b) picoeukaryotes (Peuk) and (c) nanophytoplankton (Nan) in the treatments. Abundances are presented in thousand or million cells per mL. Signs $\left(^{*}\right)$ and (+) indicate a significant density and access to sediment effects ( $\mathrm{p}<0.05)$, respectively (using two-way analysis of variance). Sign $(\mathrm{x})$ indicate significant differences $(\mathrm{p}<0.05)$ between daily values (using the KruskalWallis test). 

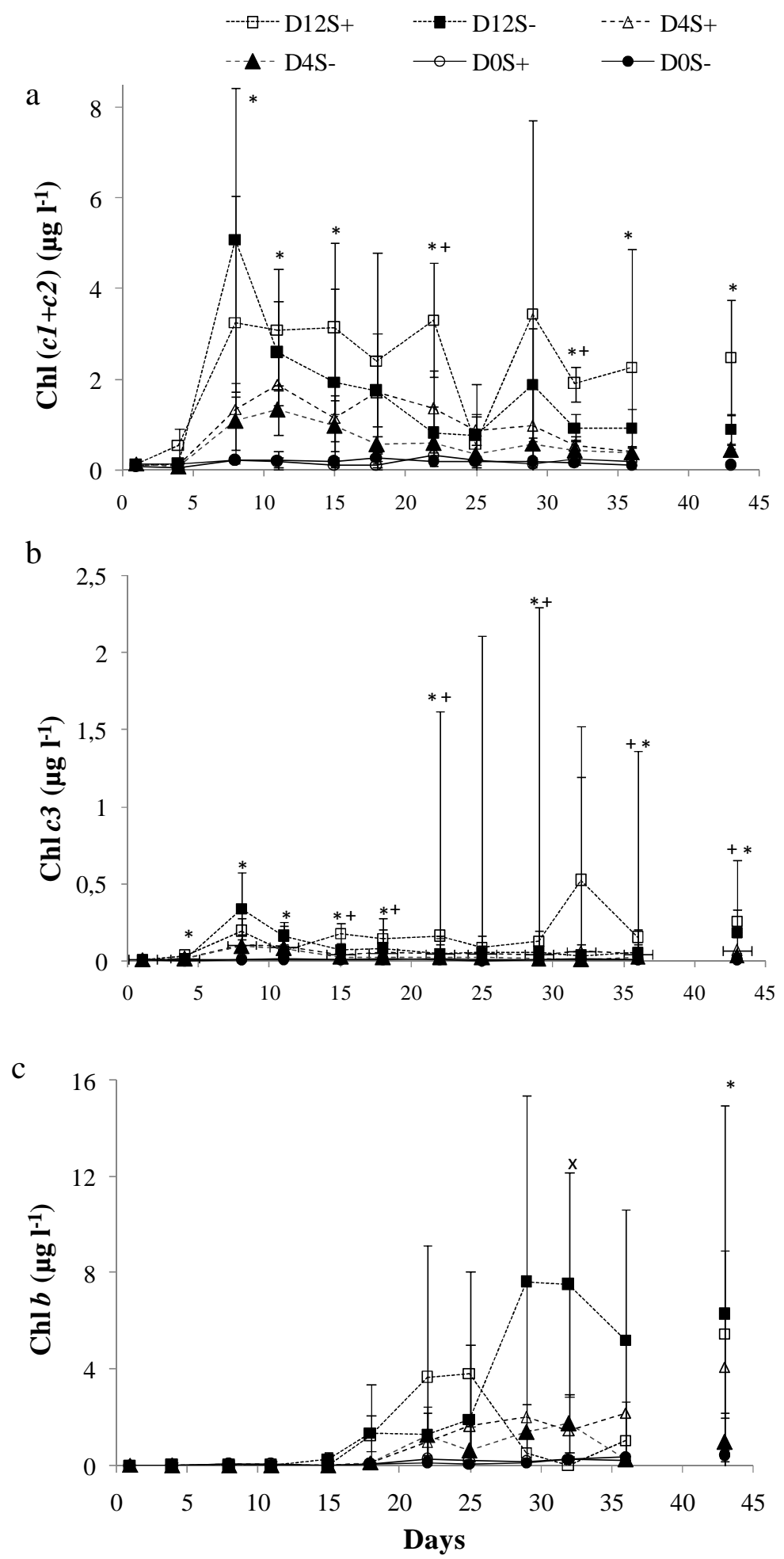

Fig. 5: Temporal mean $( \pm$ S.D. $)$ variations of water pigment concentrations as analysed by spectrofluorimetry. Signs $(*)$ and $(+)$ indicate a significant density and access to sediment effects $(\mathrm{p}<0.05)$, respectively (using two-way analysis of variance). Sign (x) indicates significant differences $(\mathrm{p}<0.05)$ between daily values (using the Kruskal-Wallis test). 


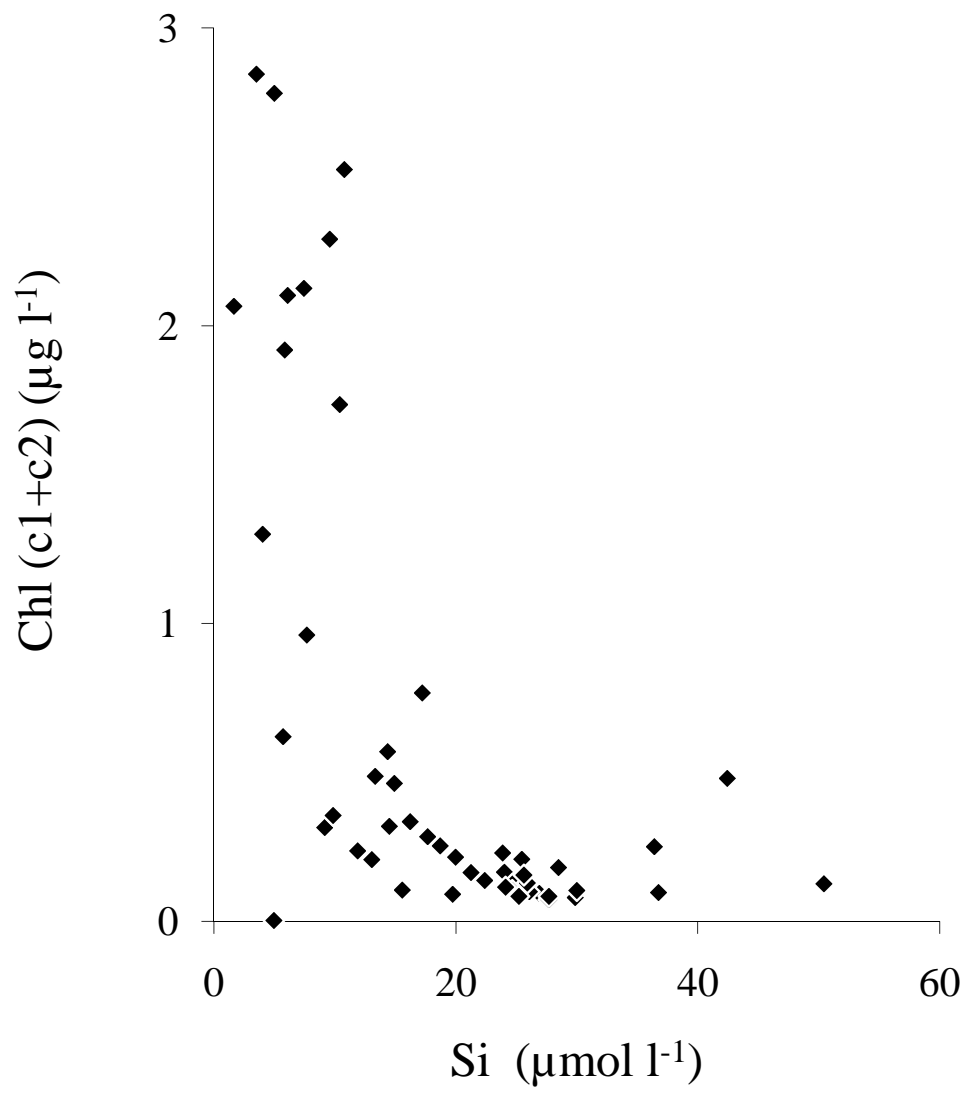

Fig. 6: Relationship between silicate concentrations and $\mathrm{Chl}(c 1+c 2)$ in the samples. 


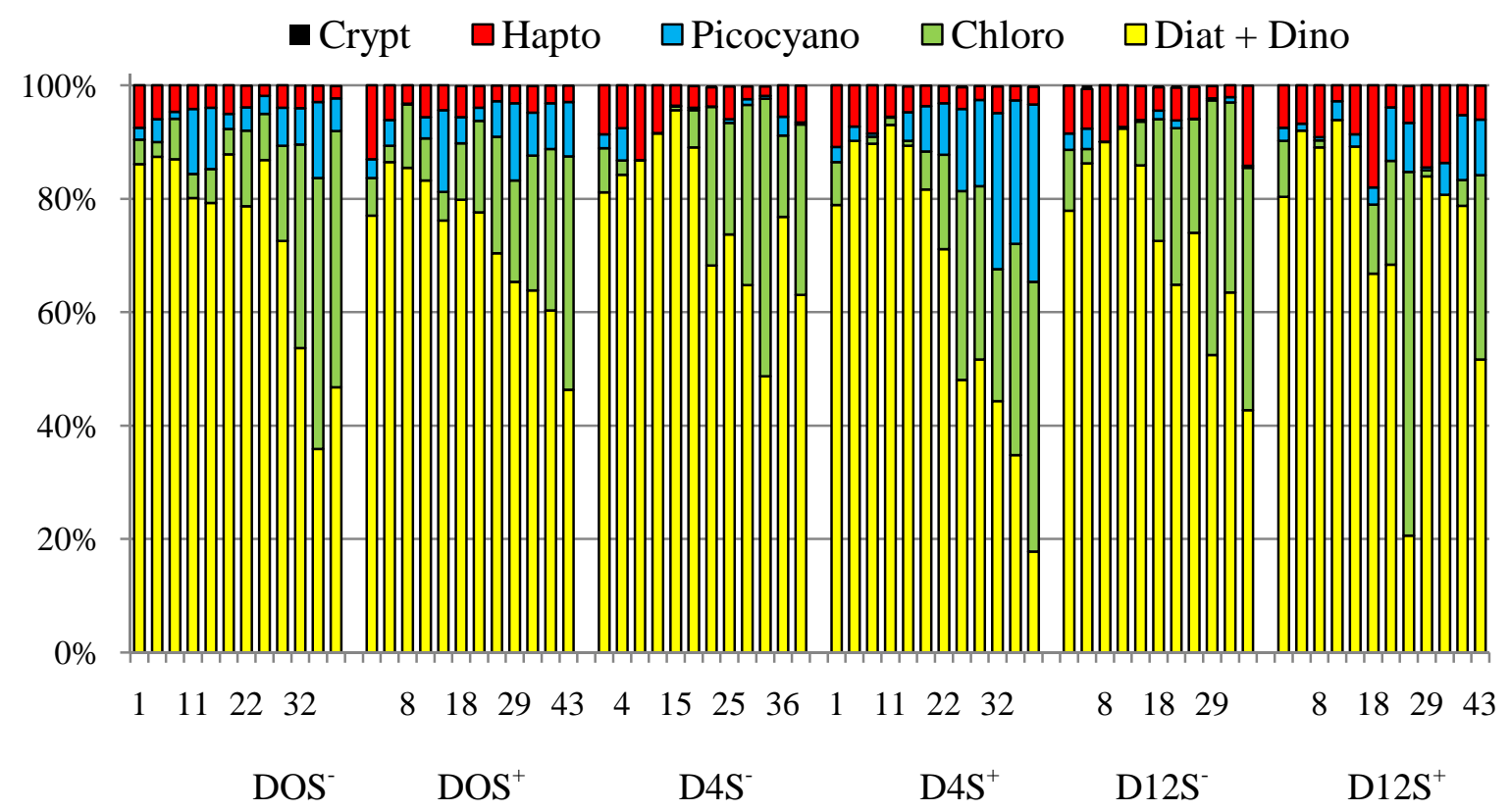

Fig. 7: Temporal mean variations of the Tchl $a$ contribution of each algae group as revealed by spectrofluorimetry, according to treatments. 


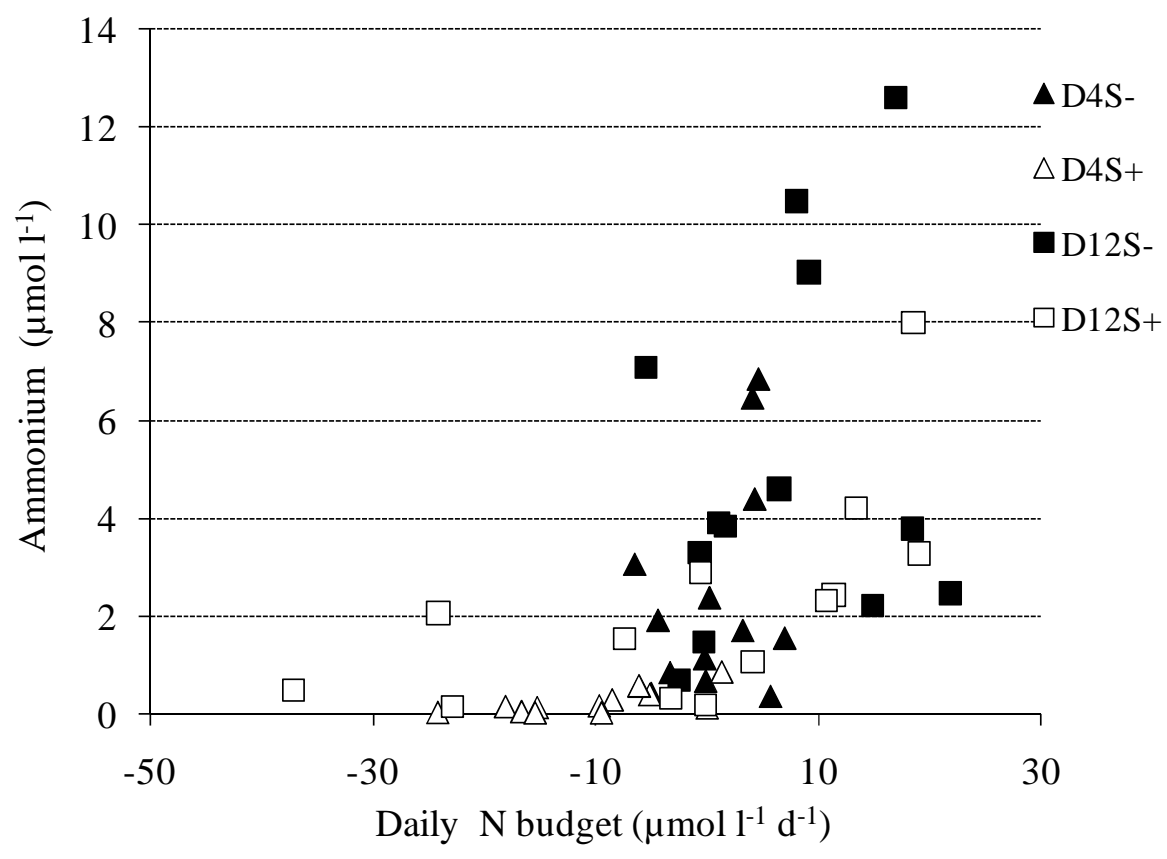

Fig. 8: Relationship between daily ammonium budget and ammonium concentration in the water column. 
Table S1: Summary of the zootechnical results after 44 days and effects of shrimp density (D) and access to the sediment (S). Statistical comparisons were carried out by a two-way analysis of variance (ANOVA), with $\mathrm{D}$ and $\mathrm{S}$ as major sources of variance (F-values are shown in the right part of the table). Values in bold type are significant at $\mathrm{P}<0.05$.

\begin{tabular}{|c|c|c|c|c|c|c|c|}
\hline & \multicolumn{4}{|c|}{ Mean and standard deviation in each treatment } & \multicolumn{3}{|c|}{$\begin{array}{c}\text { Two way ANOVA F } \\
\text { values }\end{array}$} \\
\hline & ${\mathrm{D} 4 \mathrm{~S}^{-}}^{-}$ & $\mathrm{D}_{4} \mathrm{~S}^{+}$ & $\mathrm{D}^{2} \mathrm{~S}^{-}$ & ${\mathrm{D} 12 \mathrm{~S}^{+}}^{+}$ & $\mathrm{D}$ & $\mathrm{S}$ & $\mathrm{D} \times \mathrm{S}$ \\
\hline Survival $(\%)^{*}$ & $90 \pm 16$ & $95 \pm 8$ & $81 \pm 5$ & $90 \pm 0$ & 3.7 & 0.7 & 0.11 \\
\hline Weight $(\mathrm{g}) * *$ & $12.3 \pm 1.1 \mathrm{a}$ & $16.1 \pm 0.5 b$ & $11.2 \pm 0.2 \mathrm{a}$ & $14.5 \pm 0.4 b$ & 13.3 & 96.3 & 0.45 \\
\hline Growth $\left(\mathrm{g} \mathrm{j}^{-1}\right)$ & $0.07 \pm 0.02 \mathrm{a}$ & $0.16 \pm 0.01 b$ & $0.05 \pm 0.00 \mathrm{a}$ & $0.13 \pm 0.01 \mathrm{c}$ & $\mathbf{1 3 . 3}$ & 96.3 & 0.45 \\
\hline Biomass gain $\left(\mathrm{g} \mathrm{m}^{-2}\right)$ & $8.1 \pm 5.4 \mathrm{a}$ & $25.8 \pm 4.3 \mathrm{~b}$ & $0.4 \pm 5.9 \mathrm{a}$ & $50.6 \pm 4.2 c$ & 8.9 & 140.0 & 32.1 \\
\hline
\end{tabular}




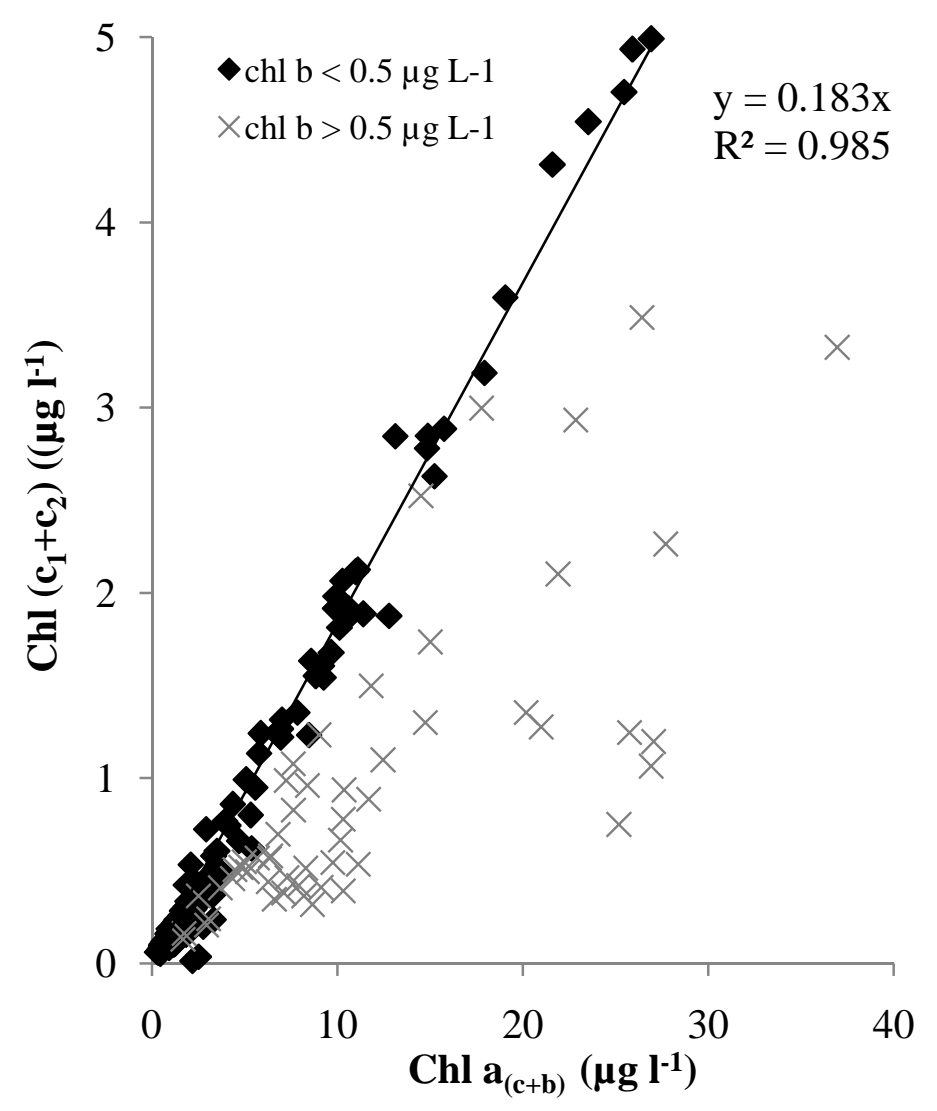

5 Fig. S1: Relation between chl $(c 1+c 2)$ and $\operatorname{chl} a_{(\mathrm{c}+\mathrm{b})} *$ for samples characterized by chl $b$ 6 concentrations less than $0.5 \mu \mathrm{g} \mathrm{l}^{-1}(\mathrm{~N}=132)$ and higher than $0.5 \mu \mathrm{g} \mathrm{l}^{-1}(\mathrm{~N}=54)$. Five pairs of 7 data characterized by significant concentrations of chl $c_{3}$ were deleted from this graph. * chl $8 a_{(\mathrm{c}+\mathrm{b})}$ : contribution of chl $a$ associated with chromophytes and green algae. 
10

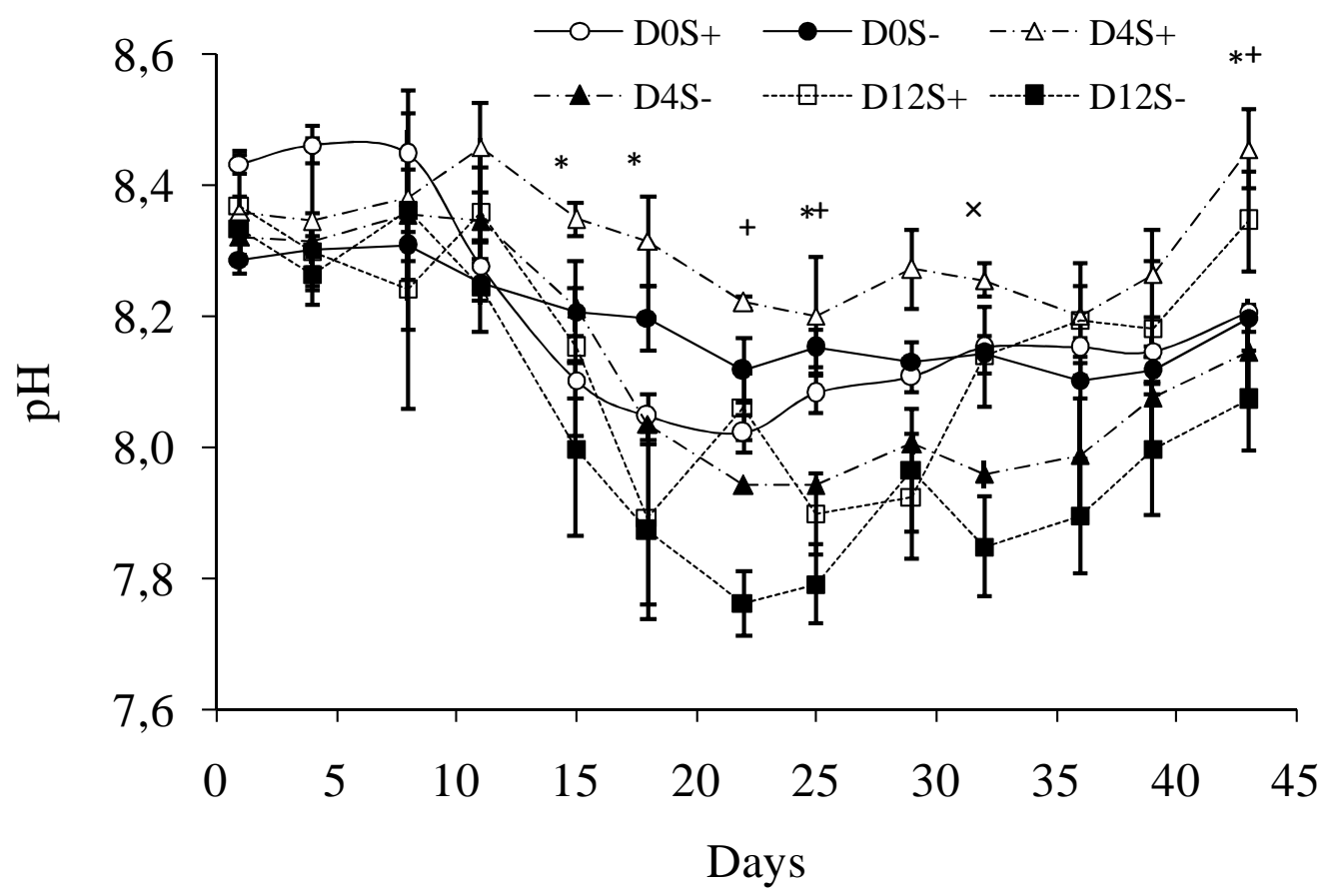

12 Figure S2: Temporal mean ( \pm S.D.) variations of $\mathrm{pH}$ measured in the water column. Signs $(*)$ 13 and $(+)$ indicate a significant density and access to sediment effects $(\mathrm{p}<0.05)$, respectively

14 (using two-way analysis of variance). Sign ( $x)$ indicates significant differences $(\mathrm{p}<0.05)$

15 between daily values (using the Kruskal-Wallis test).

16 


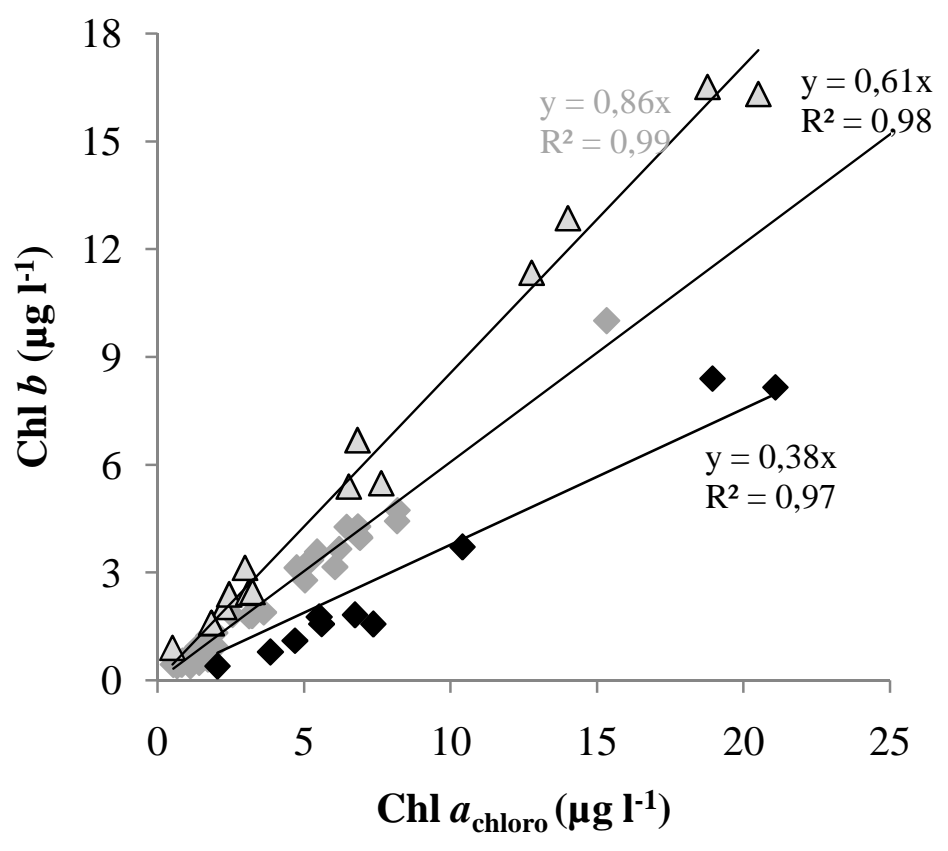

20 Fig. S3: Relationships between $\operatorname{chl} b$ (concentrations $>0.4 \mu \mathrm{g} \mathrm{l}^{-1}$ ) and $\operatorname{chl} a$ concentrations

21 associated with Chlorophytes. ( $\triangle$ : identified as prasinophytes type 3 (with prasinoxanthin);

$22(\diamond)$ : identified as prasinophytes type 1-2 (without prasinoxanthin); ( $\diamond)$ identified as 23 chlorophytes. 